\title{
Poética do contágio: estudos analíticos como mote para uma conversa entre compositores ${ }^{1}$
}

Poetics of contagion: analytical studies as a motto for a coversation between composers

Alexandre Ficagna ${ }^{2}$ Universidade Estadual de Londrina alexandre.ficagna@gmail.com 


\section{Resumo}

Estudos analíticos (formais ou despretensiosos) tomados como mote para iniciar uma conversa entre compositores, de modo a amplificar uma poética do contágio. Lido a partir de Deleuze e Guattari (1997) e Ferraz (2007), o conceito fornece uma imagem para se pensar os pequenos diálogos que permeiam o processo de criação, com foco na conversa entre compositores: conversa que pode ser diretamente verbal, mas principalmente através de suas obras, quando comumente participa a análise. Na composição de duas peças, o autor se valeu da análise para estabelecer conversas e diálogos. Em Inquietações, o contágio ocorreu por meio de estratégias técnicas e musicais, em diálogo principalmente com duas Sequenzas de Berio. Em Tons de amarelo patético, a composição ocorreu paralelamente à análise de Antiphonas, de Lima, análise que permitiu observar o contágio como modus operandi da peça em si. Pode-se pensar numa poética do contágio que se alastra epidemicamente, através de análises e conversas.

Palavras-chave: Contágio; diálogos e conversas; processo criativo; análise musical; composição musical.

\section{Abstract}

Analytical studies (formal or unpretentious) taken as a motto for a conversation between composers, seeking to amplify a poetics of contagion. From Deleuze and Guattari's (1997) and Ferraz's (2007) readings, the concept gives an image to think the small dialogues that permeate the creation process, focusing on the conversation between composers, which can occur verbally, but mainly through its works, when musical analysis is commonly used. In the composition of two pieces, the author used analytical studies to establish such conversations and dialogues. In Inquietações, the contagion occurred through the technical and musical strategies, in dialogues mainly with two Berio's Sequenzas. In Tons de amarelo patético, the composition occurred in parallel with the analysis of Lima's Antiphonas; this analysis allowed to observe the contagion as a modus operandi of the piece. One can think in a poetics of contagion, which spreads epidemically through analysis and conversations.

Keywords: contagion; dialogues and conversations; creative process; musical analysis; musical composition.

$1 \quad$ Uma versão deste trabalho foi publicada como resumo expandido em: FICAGNA, Alexandre. Análise como mote para uma conversa: elementos para uma poética do contágio In: 5 ENCONTRO INTERNACIONAL DE TEORIA E ANÁLISE MUSICAL, 5., 2019, Campinas. Caderno de Resumos. Campinas: EITAM, 2019. p.31-34.

2 Compositor, pesquisador e docente no Departamento de Música e Teatro da Universidade Estadual de Londrina (UEL). Graduação em Música/Licenciatura pela UEL, mestrado e doutorado em Música/Processos Criativos pela Unicamp. Coordena o projeto de pesquisa "Botequim de Música Contemporânea: diálogos e conversas como parte do processo criativo". http://orcid.org/0000-0003-0902-3658 


\section{Introdução: contágio}

Diferentemente da tradição filosófica neoplatônica, o filósofo Gilles Deleuze e o psicanalista Félix Guattari propõem um pensamento do devir, em oposição ao pensamento fundado no conceito de ser. Em Mil Platôs, no capítulo “Devir-intenso, devir-animal, devir-imperceptível" (DELEUZE; GUATTARI, 1997), buscando tecer imagens para que se possa compreender como o devir se propaga, eles opõem dois modelos: a filiação e o contágio.

A filiação é um modelo relacionado à organização e à hierarquia, como ocorre no modelo familiar, por exemplo. O contágio, por sua vez, relaciona termos heterogêneos, caracterizando-se por ser um "fenômeno de borda", de "aliança"; não é possível graduar, pois o que há são diferenças de natureza.

Opomos a epidemia à filiação, o contágio à hereditariedade, o povoamento por contágio à reprodução sexuada, à produção sexual. Os bandos, humanos e animais, proliferam com os contágios, as epidemias, os campos de batalha e as catástrofes. É como os híbridos, eles próprios estéreis, nascidos de uma união sexual que não se reproduzirá, mas que sempre recomeça ganhando terreno a cada vez. As participações, as núpcias antinatureza, são a verdadeira Natureza que atravessa os reinos. A propagação por epidemia, por contágio, não tem nada a ver com filiação por hereditariedade, mesmo que os dois temas se misturem e precisem um do outro. (DELEUZE; GUATTARI, 1997, p.22-23).

A partir da leitura que o compositor Silvio Ferraz faz destes conceitos ${ }^{3}$, pode-se reconhecer o regime de filiação presente nas tentativas de estabelecer genealogias ou linhas evolutivas de compositores: Bach $\rightarrow$ Beethoven $\rightarrow$ Brahms $\rightarrow$ Schoenberg, ou então, Debussy e Varèse $\rightarrow$ Schaeffer e Ligeti $\rightarrow$ Grisey e Murail. O contágio, em contrapartida, nos permite pensar não apenas na influência de um compositor sobre outro, emulando as relações de parentesco, mas no contágio que envolva compositores "não historicizados", bem como contágios entre um compositor e uma música, um som, uma imagem, um colega ou amigo por meio de uma conversa informal.

$\mathrm{Na}$ "breve nota de apresentação" de Notas.Atos.Gestos, Ferraz (2007, p.7-8) traz à tona a questão dos diálogos que atravessam o trabalho composicional, diálogos não apenas com uma "História" ou com "nomes relevantes", mas também os "pequenos diálogos" que estão à volta do que ele chama de "pequeno criador":

Quando desfazemos o "de um modo geral..." o que nasce é uma malha um tanto amorfa de pequenos diálogos, de pequenos contágios que o criador dificilmente 
consegue apagar. É assim que nem sempre sabemos de onde as ideias nos chegam para se compor uma música. E talvez seja impossível mapear este trajeto, mas ao mesmo tempo, é instigante fazer estes mapas, muitas vezes "falsificados", da gênese de nossas criações.

Segundo ele, a publicação surgiu da ideia de que, quando se compõe, nunca se está só, e de que as obras nascem em meio a uma linha "infindável e quase irreconstruível de contágios". Cada capítulo do livro é um relato composicional de um compositor diferente, não com o intuito de estabelecer um panorama da composição musical brasileira à época, mas de reunir compositores que teriam se "intercontagiado", com o argumento de que haveria uma confluência de ideias e sonoridades que perpassam suas obras. Para Ferraz, o percurso de criação de uma composição, mesmo a mais predefinida, pode mudar a partir de qualquer acontecimento, por menor que seja.

\section{A conversa como parte do processo criativo}

O tema do contágio também aparece no relato composicional de Rodrigo Lima ao mencionar a importância do "contágio afetivo" para o seu processo criativo.

Segundo Lima (2009, p.121) tal contágio é uma espécie de estímulo que "coloca em movimento uma ideia, uma ação, um desejo, um fazer". Em seu processo de criação, o compositor sugere que tais contágios podem emergir de uma improvisação despretensiosa ao piano, quando "num dado instante nosso ouvido se vê assaltado por uma determinada passagem harmônica ou mesmo por um pequeno gesto sonoro". Lima menciona ainda a possibilidade do contágio se manifestar a partir da leitura de um poema, de uma partitura, ou mesmo de uma conversa informal com um amigo, embora não dê exemplos concretos de como estes contágios atuam em seu processo composicional.

Para o compositor italiano Luca Belcastro, a conversa entre compositores é fundamental para o propósito do seu Método para Procesos Creativos Compartidos (BELCASTRO, 2017), que é o compartilhamento dos processos de criação. O método de Belcastro é estruturado de modo a constantemente convidar os participantes a conversar entre si, sobre como estão lidando com os desafios de cada etapa.

Conversar, escutar, contribuir para o processo dos demais, ajudam a aclarar cada vez mais as ideias, sensações, intuições; a aprender; a viver de maneira mais consciente os elementos que aparecem, as decisões que vão tomando. Encontram-se respostas e vislumbram-se soluções. (BELCASTRO, 2017, n.p., tradução nossa) $)^{4}$. 
Seu método é estruturado em três etapas (exploração emocional-imaginativa, elaboração narrativa e realização técnica), com diversos passos progressivos em cada uma. Para ele, o trabalho em colaboração multiplica perspectivas e soluções possíveis, envolvendo os participantes numa aprendizagem mútua. Pode-se considerar que seu método sistematiza e estimula o contágio entre os participantes das "residências" por ele conduzidas 5 .

Por outro lado, Ferraz vê em seu projeto de "reescrituras" uma possibilidade de conversar com outros compositores, com suas ideias e propostas, a despeito de qualquer empecilho geográfico ou temporal. Ele afirma que compõe como alguém que busca uma conversa e complementa: "De certo modo, sempre que escrevo música, estou em conversa com alguém" (FERRAZ, 2012a, p.294). Para ele, o tema das conversas e as reescrituras se cruzam: estas são como a tentativa de alguém que tenta imitar a maneira de falar da outra pessoa com quem conversa, ou que se esforça para falar na língua do outro, sem contudo esquecer a própria língua (FERRAZ, 2012a, p.295).

O exemplo fornecido pelo compositor é sua obra Veronica Nadir (FERRAZ, 2012a, p.304 et seq.) e a reescritura das Procissões do Encontro e do Enterro, de Manoel Dias de Oliveira. Outro exemplo, fonte de um relato composicional mais antigo, é Litania, para quarteto de cordas, em que a imagem da linha, seus feixes e cruzamentos se conectam com "Erbarme dich mein Gott", da Paixão Segundo São Matheus de Bach (FERRAZ, 2011, s.p.).

É importante destacar que Ferraz busca pensar sua música como conversas:

[...] compor música é engendrar uma conversa de sons, e não uma simples conversa com sons. Ou seja, na conversa musical, os sons emergem como sendo as próprias personagens da conversa. [...] Ainda nesta conversa, sons podem conversar com linhas, pontos, texturas, fatos, personagens. (FERRAZ, 2012a, p.295).

Embora a própria música possa ser concebida como conversa, como propõe Ferraz, aqui interessa investigar a conversa no processo do fazer composicional, como parte do processo, em que os contágios ocorrem, na maioria das vezes, de modo imprevisível e com consequências tão imprevisíveis quanto.

\section{Composição, análise e conversa}

Análise e composição interagem de diversas formas, como aponta Paulo de Tarso Salles (2010, p.13): um exercício de composição pode partir de uma análise visando obter alguns resultados, por meio de determinadas técnicas, e ainda como uma ferramenta de avaliação estética destes resultados. A composição mais livre, por sua vez, va-

5 Belcastro considera até salutar o aspecto terapêutico que possa advir de tais trocas, mas aqui o método é abordado por estimular o contágio entre os participantes desde as primeiras etapas do processo de criação. 0 método prevê a presença de um guia ou alguém mais experiente, como uma maneira de permanecer no caminho proposto e, segundo ele, "melhor aproveitar". Sobre as residências artísticas conduzidas pelo compositor, ver: GERMINA.CCIONES: primaveras latinoamericanas. Disponivel em: <http://residencia.germinaciones.org/>. Acesso em: 11 mar. 2020 
le-se da análise como ferramenta para avaliar potencialidades, possibilitando a tomada de decisão quanto à sua exploração (ou não) e eventuais combinações. A análise pode também ter como objetivo compreender como algo "funciona" ou ainda "propor um campo de apreciação técnica comum para diversos fenômenos estilísticos".

Ferraz também vê a análise imbricada no fazer composicional, seja na busca pela compreensão do "como fazer" e na avaliação de potencialidades, tal como apontado por Salles, seja como uma maneira de entrar em contato com o pensamento de outros compositores.

$O$ ato de analisar sempre se estendeu para fora dos domínios restritos do verbal. E, nesse campo aberto, compor é analisar. Analisar não significa necessariamente se deter sobre uma única obra, ou um conjunto de obras de um autor qualquer. Analisar significa também percorrer as entranhas dos objetos sonoros que estamos trabalhando no ato de composição - modos de encadeamento, de transformação, de justaposição, de contraposição. Esse ato implica também em perceber as relações do material em uso com o mundo sonoro que o rodeia: outras músicas que já o utilizaram, referências históricas, referências culturais, recordações...

Dar grande atenção à análise de obras diversas nos cursos de composição significa com isso perceber os outros compositores, ouvir suas propostas, suas resoluções para problemas pertinentes a qualquer músico. Significa abrir os ouvidos e a mente... (FERRAZ, 1994, p.132).

Nesta perspectiva, vê-se que também o estudo analítico possibilita dialogar e conversar com obras e autores. A maneira como Ferraz concebe a conversa (e seu próprio fazer composicional) cruza duas possibilidades de contágio levantadas por Lima: a da leitura de uma partitura e a da conversa informal. Enquanto a segunda possibilidade foi mencionada por Lima e perpassa, em Belcastro, todo um método que visa à troca e ao compartilhamento, a primeira possibilidade está relacionada ao estudo analítico, formal ou despretensioso. Assim, a análise passa a ser um pretexto ou um mote para a realização de uma conversa entre compositores, e a conversa, uma maneira de mobilizar o ato criativo por meio de contágios.

\section{Os contágios a partir de estudos analíticos despretensiosos em Inquietações}

A maioria das conversas e diálogos que atravessaram a composição de Inquietações (FICAGNA, 2017a), para clarinete solo, foi abordada num trabalho publicado anteriormente (FICAGNA, 2018). Naquele trabalho, buscou-se mostrar como a composição da peça travou conversas de diversas naturezas: com os sons da flauta de Salvatore Sciarrino (os bisbigliandos de All'aure in una lontananza), com os perfis do fraseado dos improvisos de Charlie Parker, com "não músicas", como as ideias dos artistas visuais Paul Klee e Wassily Kandinsky. Também houve as conversas de natureza verbal, seja no aprendizado oriundo de um curso realizado à época, seja na conversa informal com um amigo e colega do mesmo curso. Não convém retomar todos estes diálogos, uma vez 
que o foco aqui são os contágios que surgiram por meio de estudos analíticos de obras ou fragmentos de obras.

Ainda que despretensiosas e breves, análises permitiram "conversar" com o compositor Luciano Berio a respeito de fragmentos de suas Sequenzas: a IXa, também para clarinete, e a VIII, para violino. Embora os aspectos gerais do diálogo com a Sequenza para clarinete estejam na publicação mencionada no parágrafo anterior, aqui as conclusões analíticas serão expostas com mais detalhe. Além disso, o diálogo com a Sequenza para violino não consta naquela publicação.

As Sequenzas de Berio são peças solo conhecidas por propor desafios virtuosísticos aos instrumentistas. Compostas em colaboração com os intérpretes a quem são dedicadas, elas condensam diversos recursos explorados pela música instrumental do século XX sem abandonar aspectos idiomáticos dos instrumentos. Compreender o modo como Berio explorou o clarinete é como tomar contato com uma espécie de "estado da arte" da composição solo pós-serial. Evidentemente, a maneira como Berio trabalha os recursos do instrumento está diretamente ligada às técnicas musicais oriundas de sua poética musical. O contágio, portanto, transcende a mera observação dos recursos instrumentais.

O contágio, embora imprevisto, frutificou a partir de uma necessidade. A composição de Inquietações havia chegado a um ponto que, tendo elaborado um arco melódico a partir de procedimentos seriais, era preciso pensar nas possibilidades de transformação desse material inicial ${ }^{6}$.

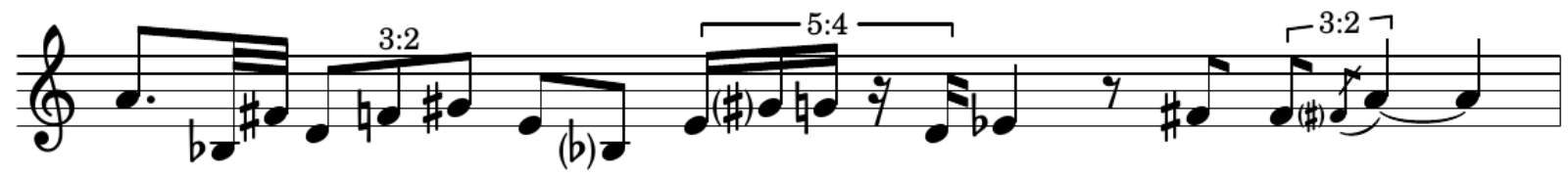

Fig. 1: Arco melódico inicial de Inquietações (sem dinâmicas e articulações). Fonte: Ficagna (2018, p.5)7.

Da análise da seção A da Sequenza surgiu a ideia de desdobrar este material, mantendo suas qualidades, mas produzindo diferenciações. Na seção em questão, cria a impressão de que os movimentos melódicos se repetem, sem serem os mesmos, por meio da sobreposição de duas rotações de elementos não sincrônicas. A técnica consiste em deslocar as notas uma a uma - notas que estão fixas em suas posições na tessitura -, ao passo que as configurações rítmicas são deslocadas para o tempo seguinte (sendo a semínima a unidade de tempo). O final de cada rotação é marcado pela repetição da nota inicial, numa duração longa, passando à nota seguinte da sequência na retomada da movimentação melódica. A única direcionalidade observável é o uso do legato, que a cada rotação agrupa unidades gestuais cada vez menores, criando a impressão de haver mais unidades gestuais retomadas.

\footnotetext{
6 Este arco melódico e suas transformações deram origem aos primeiros materiais "concretos" da composição. Contudo, decisões composicionais posteriores deslocaram-no do início da peça para a segunda seção, "Instável".

7 Os exemplos das peças para clarinete estão na transposição usual do instrumento em Si bemol. Todos os demais exemplos estão em
} som real. 
Em resumo, a análise possibilitou extrair os seguintes princípios:

- Deslocamento nota a nota de um conjunto limitado de alturas:

- alturas fixas na tessitura;

- final marcado pelo retorno da primeira nota;

- nota seguinte inicia nova rotação.

- Deslocamento das configurações rítmicas por unidade de tempo:

- final marcado por longa duração.

- Direcionalidade: fragmentação gradual do fraseado a cada iteração.
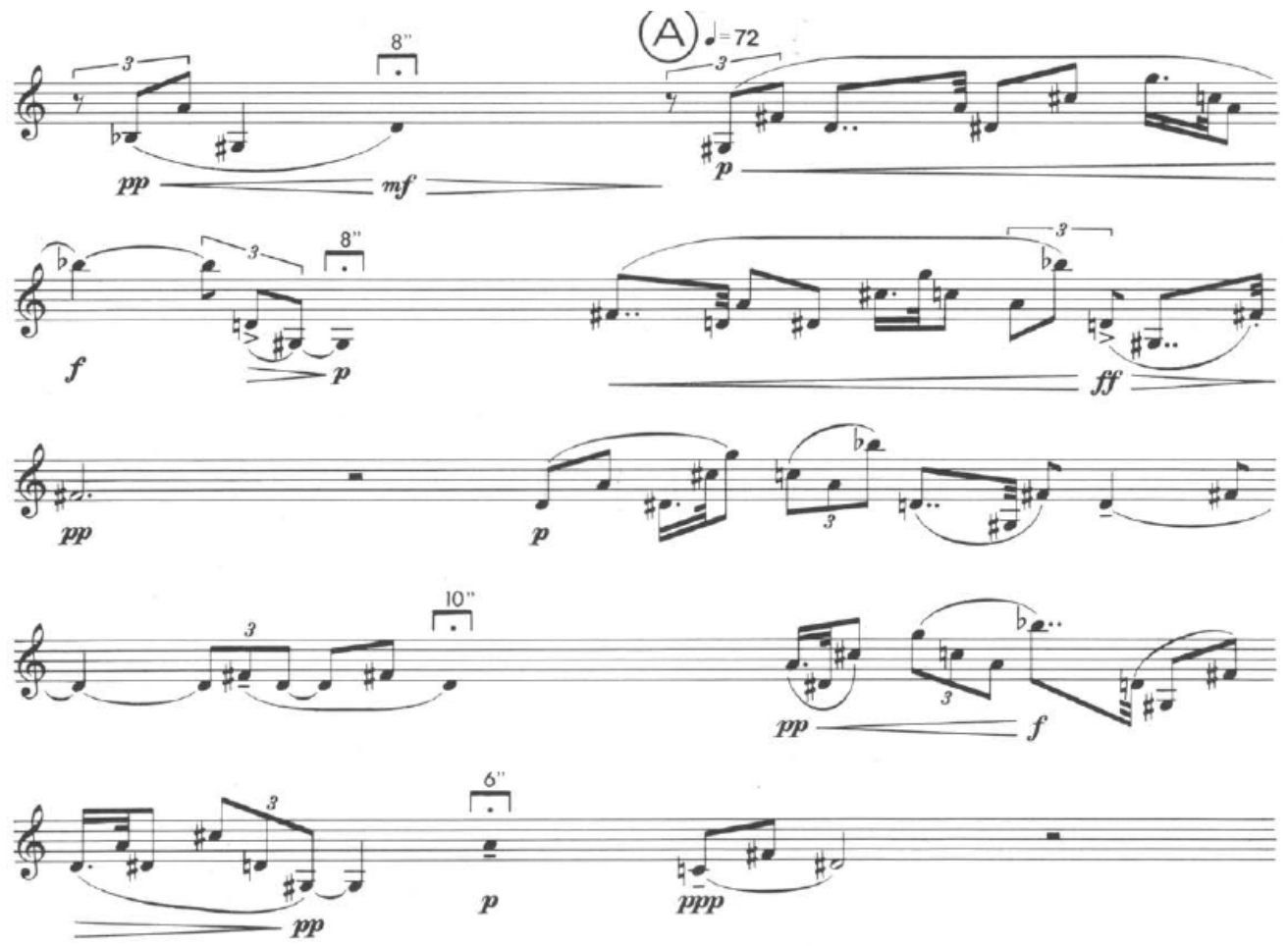

Fig. 2: Luciano Berio, Sequenza IXa, primeira metade da seção A. Universal Edition

Praticamente todos estes procedimentos foram aplicados ao material melódico inicial de Inquietações, com a diferença de que, para demarcar cada rotação, os dois últimos não rotacionam, somente os cinco primeiros. 


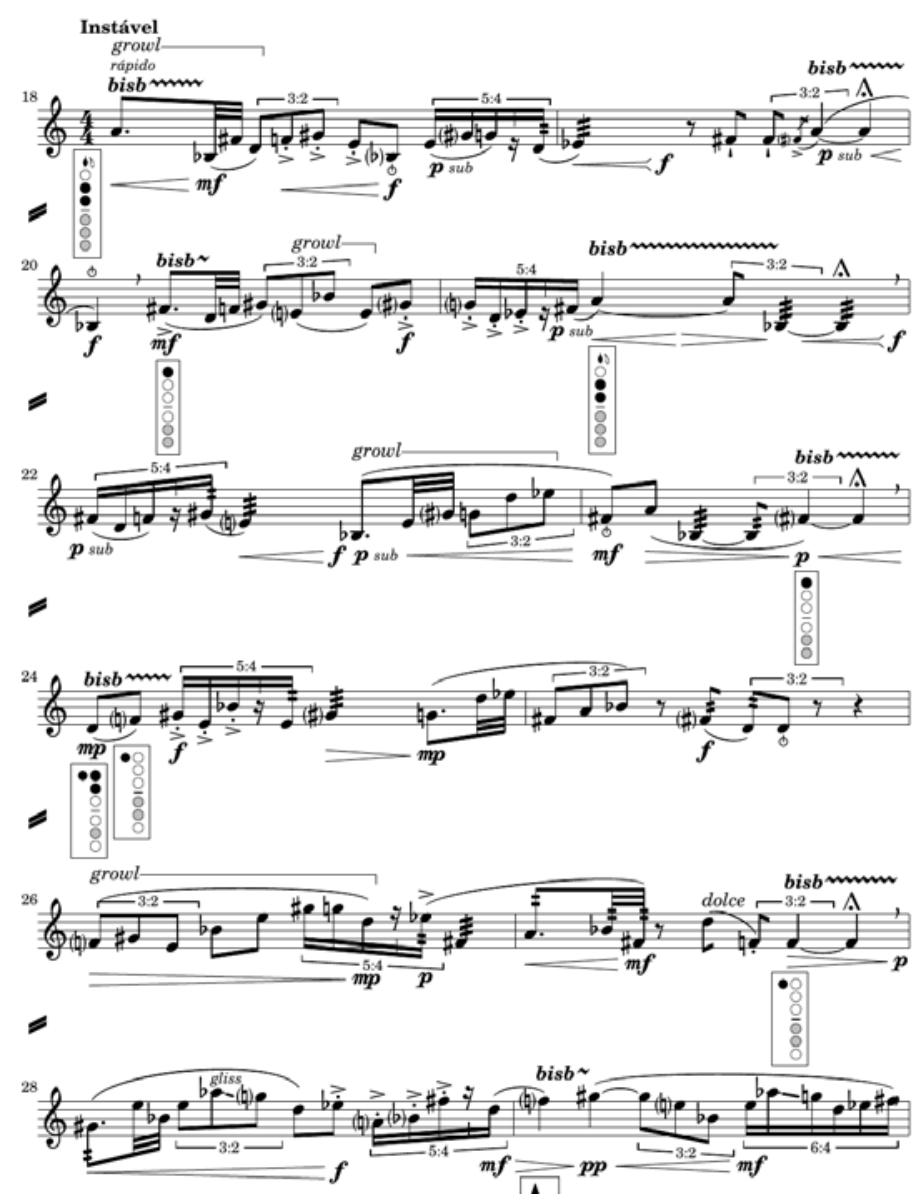

Fig. 3: Inquietações, c. 18-29: ciclo completo de rotações rítmicas; ao final, aumento de mobilidade.

Outra diferença em relação à Sequenza foi a criação de uma direcionalidade global expandida para mais elementos:

- Fraseado e articulação: as primeiras rotações iniciam com intensa fragmentação e permutação de articulações e dinâmicas, criando a impressão de maior agitação gestual; nas últimas rotações predominam o legato e as frases mais longas;

- Dinâmica: mais contrastes abruptos no início; evoluções mais contínuas ao final;

- Ocupação da tessitura: inicialmente concentradas na região chalumeau do instrumento, a cada rotação algumas notas eram transpostas para a oitava superior; ao final, quase todas as notas encontram-se na região do clarino;

- Bisbigliandos: bastante presentes nas primeiras rotações, vão sendo eliminados paulatinamente ao longo das rotações.

No decorrer da composição, após atingir a nota mais aguda da peça e antes da seção de caráter mais energético ("Selvagem"), a imagem musical de outra peça de Berio, o início da Sequenza VIII, para violino, condensava uma série de características que permitiram criar uma impressão de retenção de movimento e acúmulo de energia. Trata-se da seção "Solene", que antecede e se alterna com a seção "Selvagem".

No início desta Sequenza, Berio praticamente só utiliza a nota Lá central: mesmo quando agrega outras notas, o compositor parece interessado em nos fazer ouvir esta 
nota como um som com variações de espessura, e não necessariamente o conteúdo harmônico resultante dos eventuais intervalos de segunda maior ou menor; a utilização de uníssonos parece reforçar este propósito.

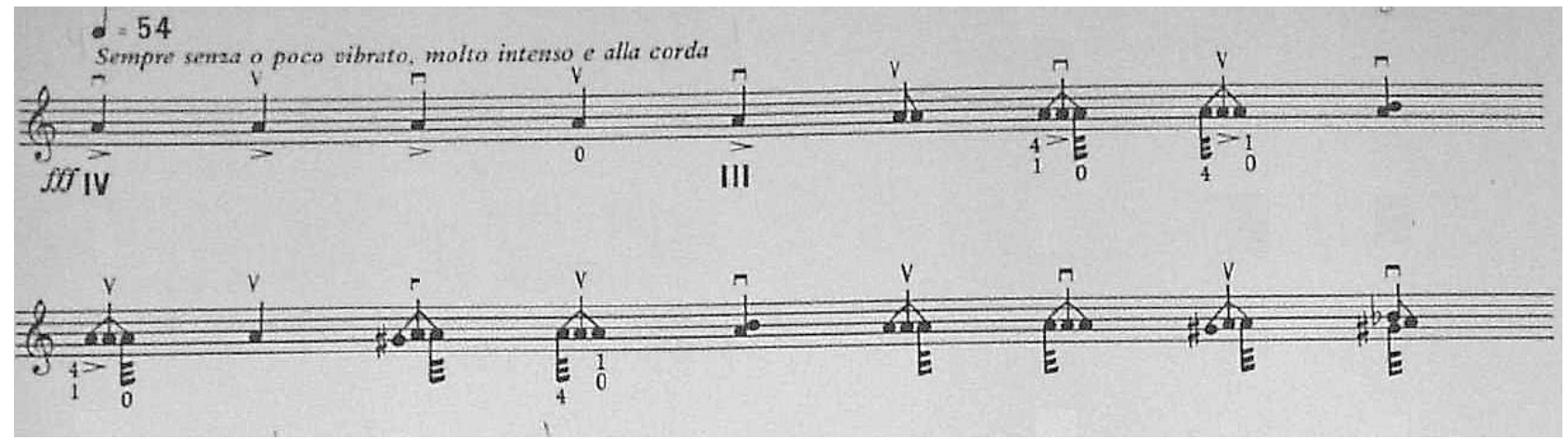

Fig. 4: Luciano Berio, Sequenza VIII, início. Universal Edition.

Esta maneira de utilizar o instrumento é muito particular do violino, e seria muito difícil conseguir um efeito semelhante no clarinete. Porém, a análise desta passagem permitiu observar uma espécie de "princípio de compensação": contrapondo a previsibilidade de diversos parâmetros - alturas, ritmo (20 semínimas em sequência), dinâmica (fff constante) - e das arcadas (alternância constante: ora do talão para a ponta, ora da ponta para o talão), o compositor distribui de modo imprevisível os modos de articulação e os elementos agregados ao início das semínimas (notados como fusas), fatores ligados principalmente à percepção do ataque de cada som. De certo modo, aquilo que foi encontrado indiretamente na análise da Sequenza para clarinete - a estaticidade movente - aqui se encontra de maneira mais sutil e condensada: a imobilidade da nota versus a mobilidade dos modos de ataque e sustentação dos sons.

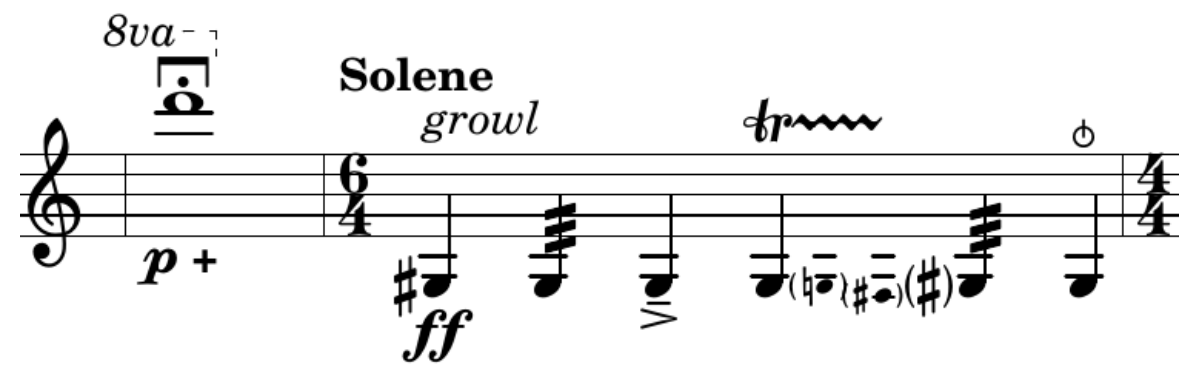

Fig. 5: Inquietações, c. 46-47: primeira irrupção de "Solene", após nota mais aguda da peça e antecedendo o início de "Selvagem".

Enquanto na introdução da peça de Berio outras alturas vão sendo "agregadas" à nota repetida, em "Solene" as notas mudam nas irrupções seguintes. Apesar da previsibilidade rítmica e dinâmica, há "compensação" em dois aspectos, introduzindo sutis imprevisibilidades: o número de notas repetidas não possui um padrão; as articulações, permutadas, mudam a cada unidade - a imprevisibilidade mistura elementos ligados ao ataque dos sons (ordinário, acento, slap tongue) e à sustentação (som normal, growling, trinados duplos, frulatos). 
Embora a análise tenha permitido extrair ferramentas para a criação de um comportamento semelhante em nível morfológico, ela permitiu elaborar uma maneira de ler o início da Sequenza e ver ali um princípio composicional que passou a orientar a composição de Inquietações. Tanto "Selvagem" quanto "Solene" podem ser lidas a partir da ideia de compensação entre instabilidade e estabilidade, seja em sua constituição interna, seja na dinâmica de alternância entre ambas.

De todos os contrastes entre "Selvagem" e "Solene", o mais notável é o rítmico: não só o andamento é diferente, mas ritmicamente há um corte da imprevisibilidade e agitação para previsibilidade e imobilidade (congelamento da semínima). Uma sensação rítmica muito mais lenta se estabelece, devido à mudança das notas repetidas. Com a progressiva diminuição de intensidade de "Selvagem", aumenta também o contraste dinâmico, uma vez que "Solene" permanece sempre em ff.

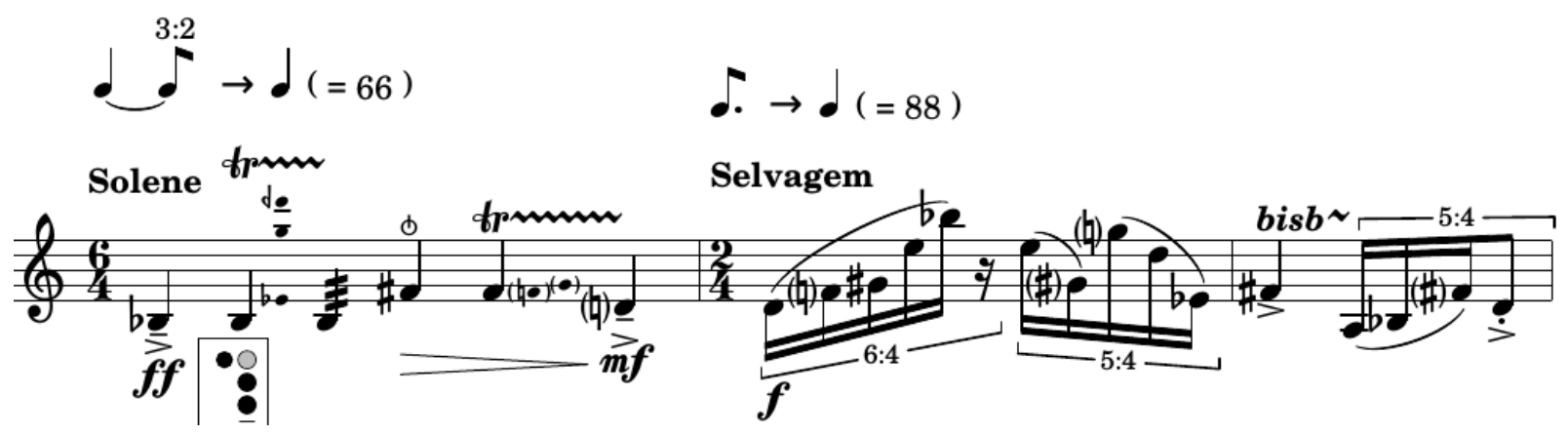

Fig. 6: Inquietações, c. 53-57: segunda irrupção de "Solene", antecedente ao retorno de "Selvagem".

Outra diferença está no tamanho das seções, que possuem tendências opostas: as inserções de "Solene" duram, em semínimas, 6, 6, 7 e 11; as inserções de "Selvagem", 22, 13,8 , estabilizando em torno de 15 (quando as indicações de expressão passam a ser "Apreensivo" e "Murmurando").

A tabela a seguir resume o mecanismo de compensação em "Selvagem" e "Solene":

\begin{tabular}{|c|l|l|}
\hline & Selvagem (Apreensivo, Murmurando) & \multicolumn{1}{c|}{ Solene } \\
\hline Instabilidade & $\begin{array}{l}\text { - alturas } \\
\text { - ritmo }\end{array}$ & $\begin{array}{l}\text { - articulações } \\
\text { - número de repetições das alturas }\end{array}$ \\
\hline Estabilidade & $\begin{array}{l}\text { - dinâmica: f decrescendo a ppp } \\
\text { - articulação: legato predomina }\end{array}$ & $\begin{array}{l}\text { - dinâmica: ff } \\
\text { - ritmo: semínimas }\end{array}$ \\
\hline
\end{tabular}

Tab. 1: Mecanismo de compensação em "Selvagem" e "Solene". 
Um exemplo de como o princípio de compensação foi generalizado para o restante da peça: sempre que houvesse uma nota longa sem movimentação, lhe seria atribuída ao menos alguma mobilidade interna, seja ela dinâmica (crescendo, decrescendo, por ex.) ou de sonoridade (bisbigliando, frulato etc.). A única exceção foi a nota mais aguda da peça, pois o desafio ao intérprete ${ }^{8}$ consistia justamente em estabilizar sua sonoridade.

Estas análises despretensiosas buscavam conversar a respeito das possibilidades de abordagem do instrumento, no primeiro caso, e sobre a estratégia de criação de imprevisibilidade sobre uma mesma nota repetida, no segundo. A partir destes pontos de contato iniciais, os contágios evoluíram de maneiras imprevistas: da primeira peça observou-se a técnica de rotação, deformada, por assim dizer, no emprego de mais estratégias de direcionalidade; da segunda peça extraiu-se um princípio, o de compensação, que passou a se integrar a mais dimensões da composição.

Se em Inquietações os estudos analíticos foram um meio de travar uma conversa entre compositores, como uma forma de compartilhar soluções para problemas que se apresentavam no momento da composição, a próxima seção trata de uma composição que se dá a partir do momento em que a análise estava praticamente concluída.

\section{Os contágios a partir da análise de Antiphonas, de Rodrigo Lima}

Em termos de técnicas para geração de materiais, Tons de amarelo patético (para quarteto de saxofones) (FICAGNA, 2017b) dá continuidade ao trabalho de caráter pós-serial de Inquietações. No caso específico do segundo movimento, "Intervenção verde-oliva", foram utilizadas permutações cíclicas de séries numéricas para construir tanto a métrica alternada que controla a progressão harmônica inicial quanto os ritmos das irrupções do solista (saxofone soprano) ${ }^{9}$. Os ritmos da progressão harmônica foram extraídos de fragmentos livremente recortados das séries.

A imagem musical inicial deste movimento é XAS, de lannis Xenakis, para a mesma formação. Além da sonoridade em si, que convinha ao propósito expressivo e poético do segundo movimento de Tons de amarelo patético, o acorde inicial da peça deu origem à harmonia de "Intervenção verde-oliva", dele derivando outros acordes a partir da aplicação cíclica da série 5641373146 (derivada da série gérmen de Tons de ama-

A peça foi composta como um desafio ao clarinetista Jairo Wilkens, a quem ela é dedicada. Wilkens gravou a peça em seu CD: Clarinete Solo Brasileiro.

$9 \quad$ No projeto de pesquisa mencionado na nota 10, uma das ações consistia em estudar os muzaks de Brian Ferneyhough descritos em Malt (1999). Meu colega Fernando Kozu, que estudou o assunto, elaborou um informalmente um material didático do qual extraí as técnicas de interpolação serial e aplicação de séries-filtro. Evidentemente o resultado estético é muito diferente das obras do compositor inglês. Tais procedimentos foram associados às técnicas de permutações cíclicas exploradas em Inquietações. Além disso, houveram diversas decisões de ordem "informal" em "Intervenção verde-oliva", como as seguintes: a matriz construída a partir das rotações da série inicial foi percorrida "visualmente" e desse itinerário extraiu-se a série para as permutações do agregado harmônico inicial (cf. Fig. 7); utilização de outra série, derivada da inicial, para realizar permutações cíclicas e assim criar os ritmos dos solos do sax soprano; fragmentos das séries resultantes das permutações cíclicas que possuíssem alguma "característica marcante" foram utilizados ritmicamente com agregados harmônicos específicos, como se fossem "personagens rítmicos". Portanto, reconstruir em detalhes o itinerário técnico da peça torna-se praticamente impossível. 
relo patético $)^{10}$. O conteúdo melódico dos solos do sax soprano também deriva desta harmonia de base. O acorde inicial de XAS está contido na sequência 314 da série, e o próximo acorde dá prosseguimento ao ciclo, sendo os números a distância intervalar entre as notas adjacentes, e iniciando o acorde seguinte a partir da nota mais aguda do anterior, oitava abaixo, até atingir novamente o acorde inicial (Fig. 7 e 8).

De modo semelhante ao processo descrito em Inquietações e sua relação com a Sequenza IXa, a peça de Xenakis foi inicialmente abordada como uma referência a respeito da exploração da formação instrumental para a qual se intencionava compor. Contudo, XAS proporcionou também um estímulo de outra ordem, que se cruzou com os diversos estudos que ocorriam em paralelo (cf. nota 9).

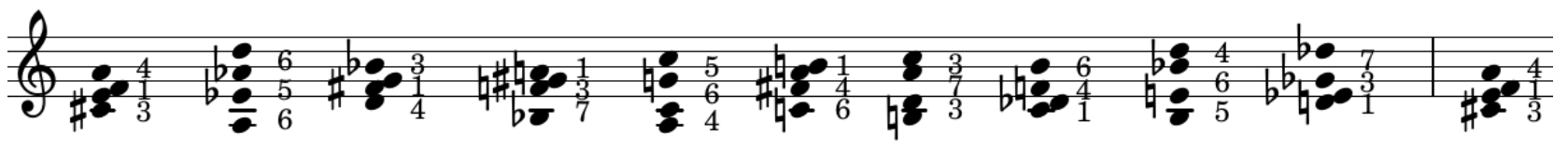

Fig. 7: Permutações cíclicas baseadas na série 564137314 6, a partir do acorde inicial de XAS.

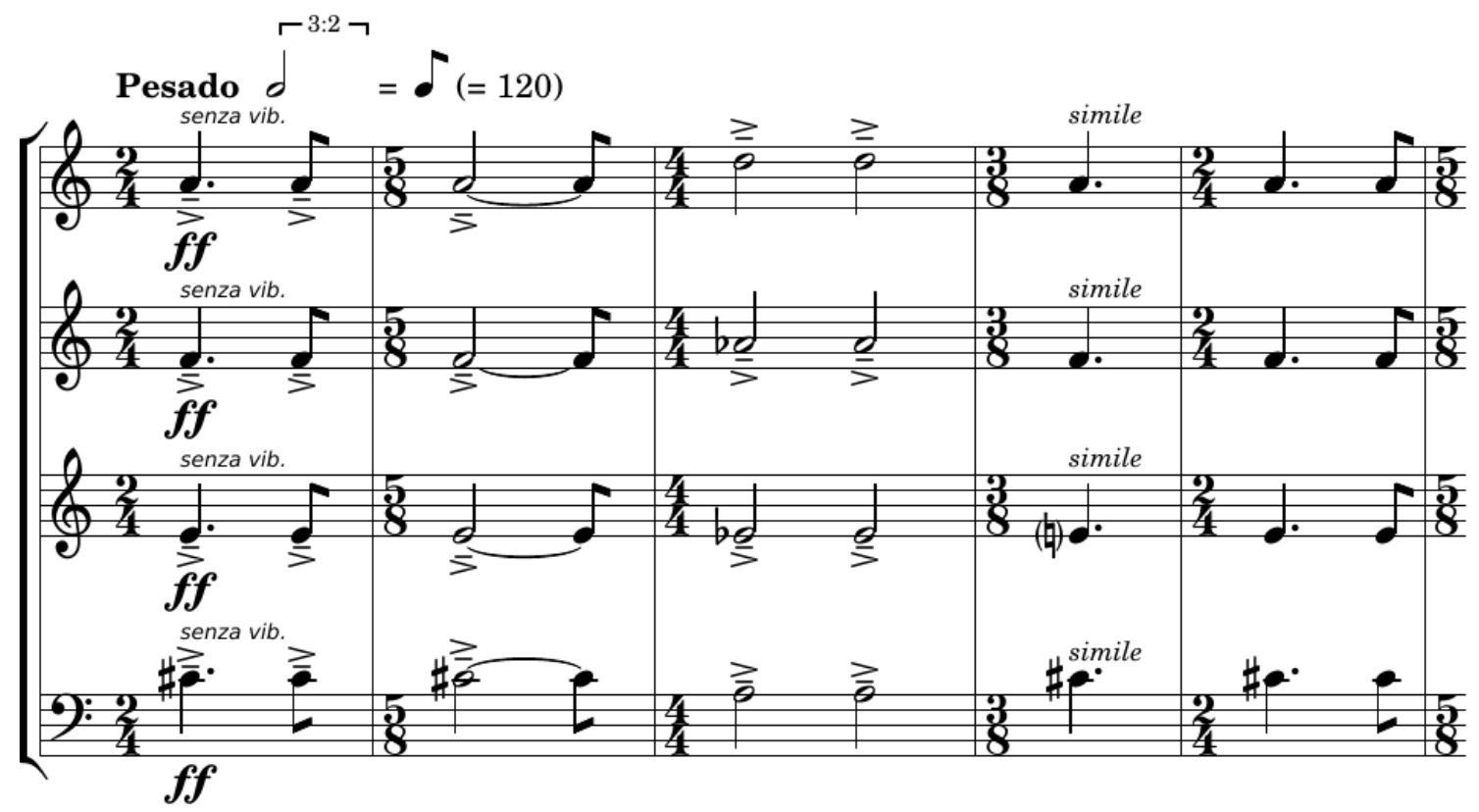

Fig. 8: "Intervenção verde-oliva": compassos iniciais.

O diálogo mais intenso deu-se com a peça de Rodrigo Lima, Antiphonas (2014), para saxofone alto e conjunto de câmara (flauta, trompete, trombone, violino, viola, violoncelo, contrabaixo, piano, percussão). A análise estava avançada à época da composição de Tons de amarelo patético, pois era uma atividade prevista em um projeto de pesquisa ${ }^{11}$.

\footnotetext{
10 Com relação às alturas, a série gérmen de todos os procedimentos de geração de material é 5273146 . Ao criar uma matriz a partir de rotações, na vertical obtém-se a coluna 5641372 . Percorrendo a matriz na vertical até o penúltimo elemento, e dele seguindo em linha (até a penúltima coluna), obtém-se a série simétrica 5641373146 , que foi utilizada para a derivação dos demais blocos harmônicos por proporcionar resultados considerados mais adequados aos propósitos expressivos da peça.

11 Botequim de Música Contemporânea: diálogos inter-composicionais, projeto de pesquisa coordenado pelo autor na Universidade Estadual de Londrina.
} 
Ainda que de tal análise se esperasse extrair princípios a serem aplicados em composições futuras, ela não foi realizada como nos exemplos anteriores, em que o estudo analítico de um curto fragmento ocorria mediante uma necessidade pontual de uma composição em andamento. Em realidade, pode-se dizer que o caminho foi inverso: a partir da análise quase completa, da sistematização do "como funciona" e da proposição de um "campo de apreciação técnica" (tal qual propõe Salles [2010]), depois de primeiro "ouvir as propostas" de Lima (parafraseando Ferraz [1994, p.132]), que se passou a pensar numa composição que dialogasse com esta análise. Este diálogo se deu somente no movimento abordado aqui (cronologicamente, o último a ser composto).

Antiphonas não será abordada em sua totalidade, mas, sim, em relação aos principais elementos (técnicos e musicais) que emergiram a partir da interpretação analítica da obra e que foram apropriados na composição de "Intervenção verde-oliva".

O primeiro aspecto consiste na utilização de notas-pivô, que estabelecem uma espécie de eixo harmônico e de sonoridade para a textura. Segundo Lima ${ }^{12}$, tais notas aparecem nas texturas como centros de referência, que vão sendo incorporados no processo de formação das texturas. Na maioria das vezes apresentam-se como ressonâncias sustentadas artificialmente; noutras, como notas repetidas que se espalham pelos instrumentos. Ainda segundo o compositor, o interesse estaria em perceber como esse centro vai sendo moldado e como se relaciona com o que vinha acontecendo na peça ${ }^{13}$. Uma das estratégias empregadas pelo compositor é a criação de rugosidades em relação ao eixo, como pode ser observado nos fragmentos a seguir.

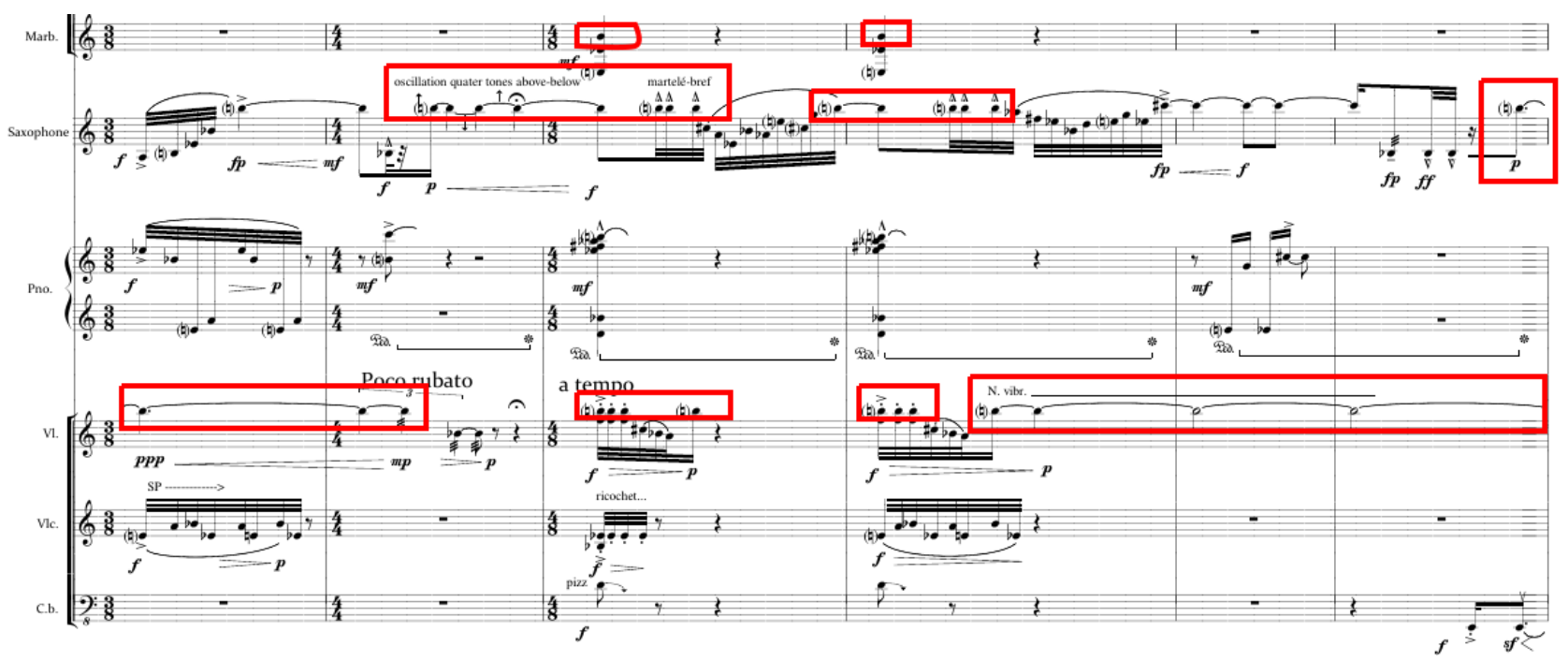

Fig. 9: Antiphonas, c. 60-65, eixo na nota Si (destaque em vermelho). prio Lima (2017), pois este se vale desta noção para relatar o processo de construção da harmonia da peça, deixando subentendida sua utilização no contexto textural.

13 Informação obtida por meio de conversa particular. É provável que Lima esteja se referindo à relação harmônica. 


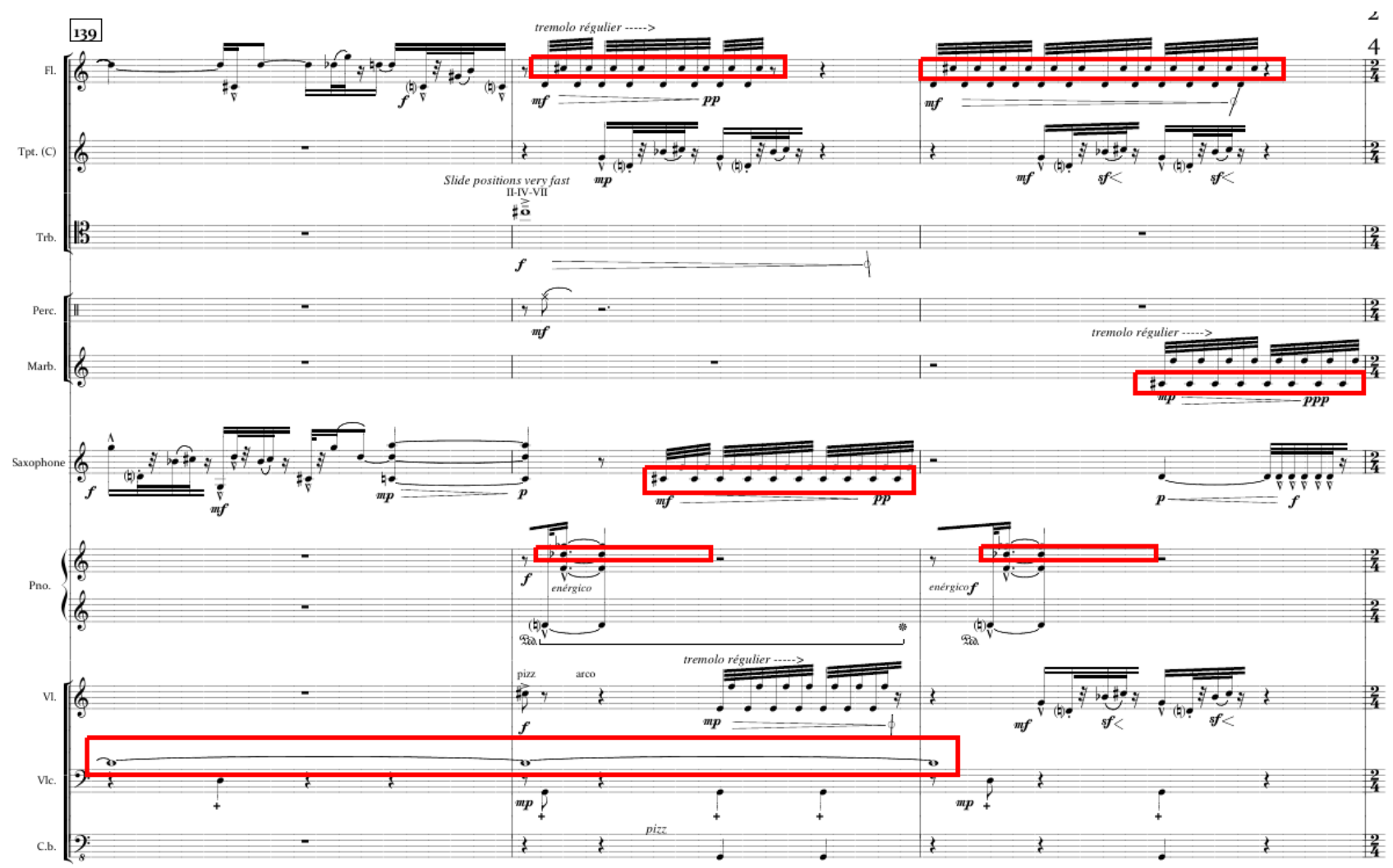

Fig. 10: Antiphonas, c. 139-141, eixo na nota Dó \# (destaque em vermelho).

Nas passagens ilustradas pelas Fig. 9 e 10, vê-se como Lima busca aumentar ou diminuir a espessura dos eixos por meio do acréscimo de determinados intervalos, como o Dó\# sustentado pelo saxofone no c. 64 (primeiro exemplo) ou o Ré sustentado pela flauta no c. 139 (segundo exemplo). Lima explora este aspecto a tal ponto que, em determinados momentos, o eixo parece ser não uma única nota, mas o intervalo entre elas, como na passagem dos c. 75-79 (uma parte pode ser vista na Fig. 13), em que a nota Ré se estabelece como novo eixo junto com o anterior (Mi, que vinha desde o c. 71).

O segundo aspecto, mais geral, está relacionado à maneira como Lima concebe a relação do solista (saxofone alto) com o conjunto de câmara. No texto sobre a obra contido na partitura (LIMA, 2014, n.p., grifo nosso), ele afirma:

Assumi a mutualidade e o aspecto ritualístico sugerido pelo título da obra como elemento propulsor dessa interação entre solista e ensemble. Porém, os diálogos não são meras respostas ou repetições, eles se projetam no tempo como uma espécie de Eco, ou "dialogue antiphonal" distorcido, criando assim um simulacro sonoro onde os pontos, linhas e texturas tendem a se deformar num jogo de construção e desconstrução de movimento e sonoridade.

Este "diálogo antifonal distorcido", tal como proposto por Lima, pode ser pensado como um contágio "intramusical", tendo na imitação um ponto de contato inicial, a partir do qual se propagam mais as diferenças do que as similaridades, como nos contágios 
entre obras mencionadas anteriormente. No caso de Antiphonas, pode-se pensar num contágio gestual ${ }^{1415}$.

O contágio gestual ocorre na peça numa via de mão dupla. A princípio, partem do solista os elementos que ecoam de modo distorcido no ensemble, como na passagem exemplificada a seguir, em que flauta e piano ecoam o saxofone, três tempos depois (Fig. 11). No compasso seguinte (Fig. 12) é possível observar tanto a deformação da sequência do gesto do saxofone na flauta e no piano quanto a expansão das três fusas repetidas do saxofone no trompete.

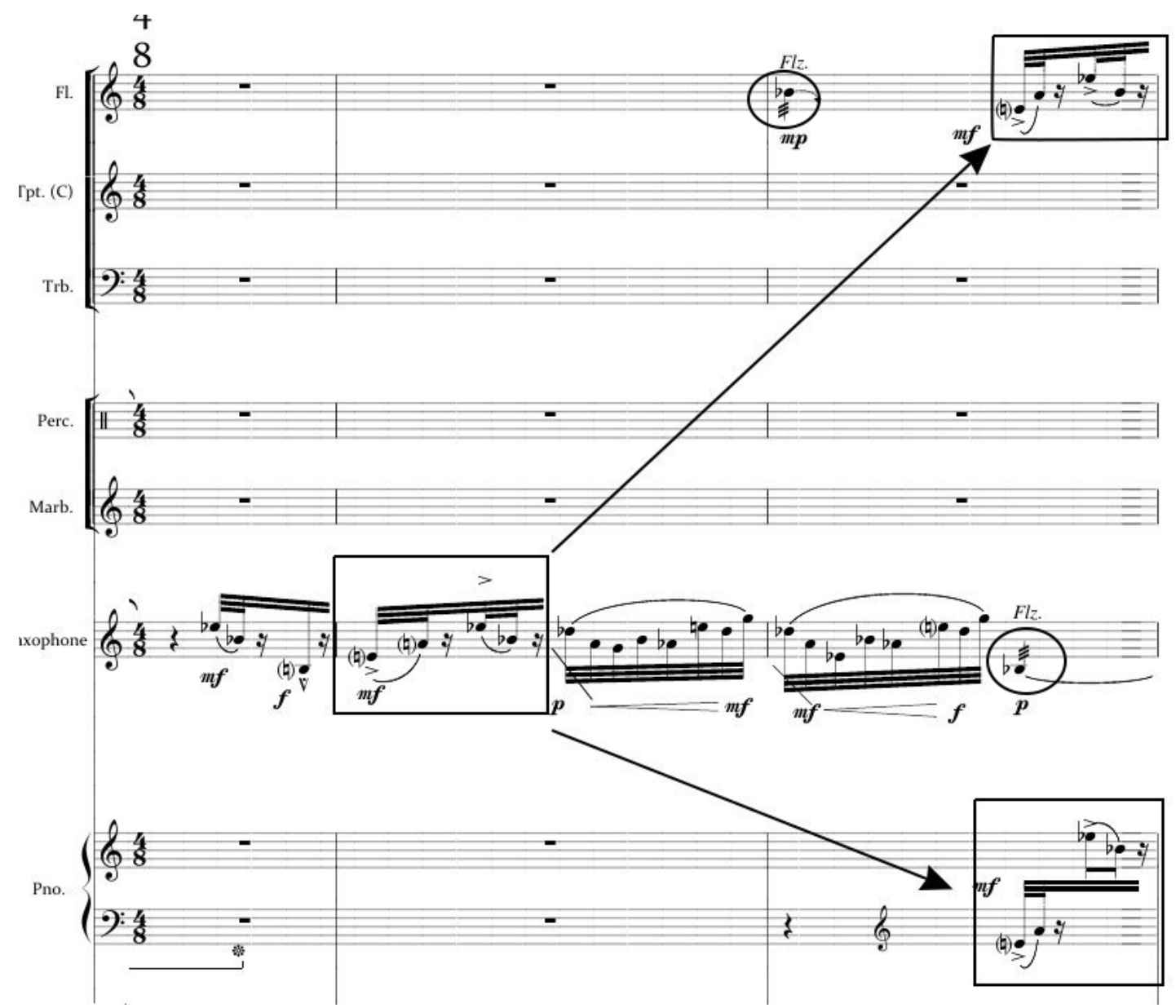

Fig. 11: Antiphonas, c. 52-54. As setas indicam a propagação. As notas circuladas são os eixos.

\begin{abstract}
14
Em conversas particulares com o compositor (LIMA, 2020), foi possível esclarecer a maneira como ele partiu da imagem do "dialogue antiphonal" de Josquin Des Préz para chegar ao "eco antifonal distorcido", e como esta imagem guiou seu processo composicional, inclusive no modo como adaptou algumas técnicas tradicionais. Primeiramente, as imitações foram utilizadas para retomar elementos distantes no tempo (daí a imagem do "eco") a partir das quais proliferam diferenças, que podem se acentuar ao sofrer "mutações" consequentes da ação de outras forças, advindas de outros contágios. É nesse sentido que se trata de um eco, mas distorcido, pois sofre deformações (cf. nota seguinte). 0 compositor também ressalta que há procedimentos de "variação" na peça, mas não no sentido de um "tema com variações", uma vez que em Antiphonas não há uma ideia de "série" ou "tema". Imitações e variações são adaptadas para fazer o tecido musical se movimentar não tanto pela manutenção das similaridades "melódicas", mas pela proliferação das diferenças. Ao se analisar a peça, pode-se atribuir a estas diferenças tanto a ação das forças gestuais intrínsecas ao material melódico, qquato extrínsecas, causadas pelos contágios. Foi por considerar todos estes aspectos que se atribuiu a tais procedimentos o termo contágio gestual. Sobre a imitação como "repetição do diferente", cf. nota 19.
\end{abstract}

15 Paul Klee afirmava que ao artista interessavam mais as forças formadoras do que as formas finais (KLEE, 2001, p.64). Gilles Deleuze retoma e expande esta questão. "Em arte", afirma Deleuze (2007, p.62), não se trata de reproduzir ou inventar formas, mas de captar forças.." 0 filósofo aborda a pintura de Francis Bacon e nela localiza a ação de diversas "forças", dentre as quais as forças de deformação. Para Deleuze, a deformação no trabalho de Bacon é um ato em si: "Tudo está em relação com forças, tudo é forças. É isso que constitui a deformação como ato de pintura: ela não se deixa reduzir a uma transformação da forma, nem a uma decomposição dos elementos." (Ibidem, p.65). 


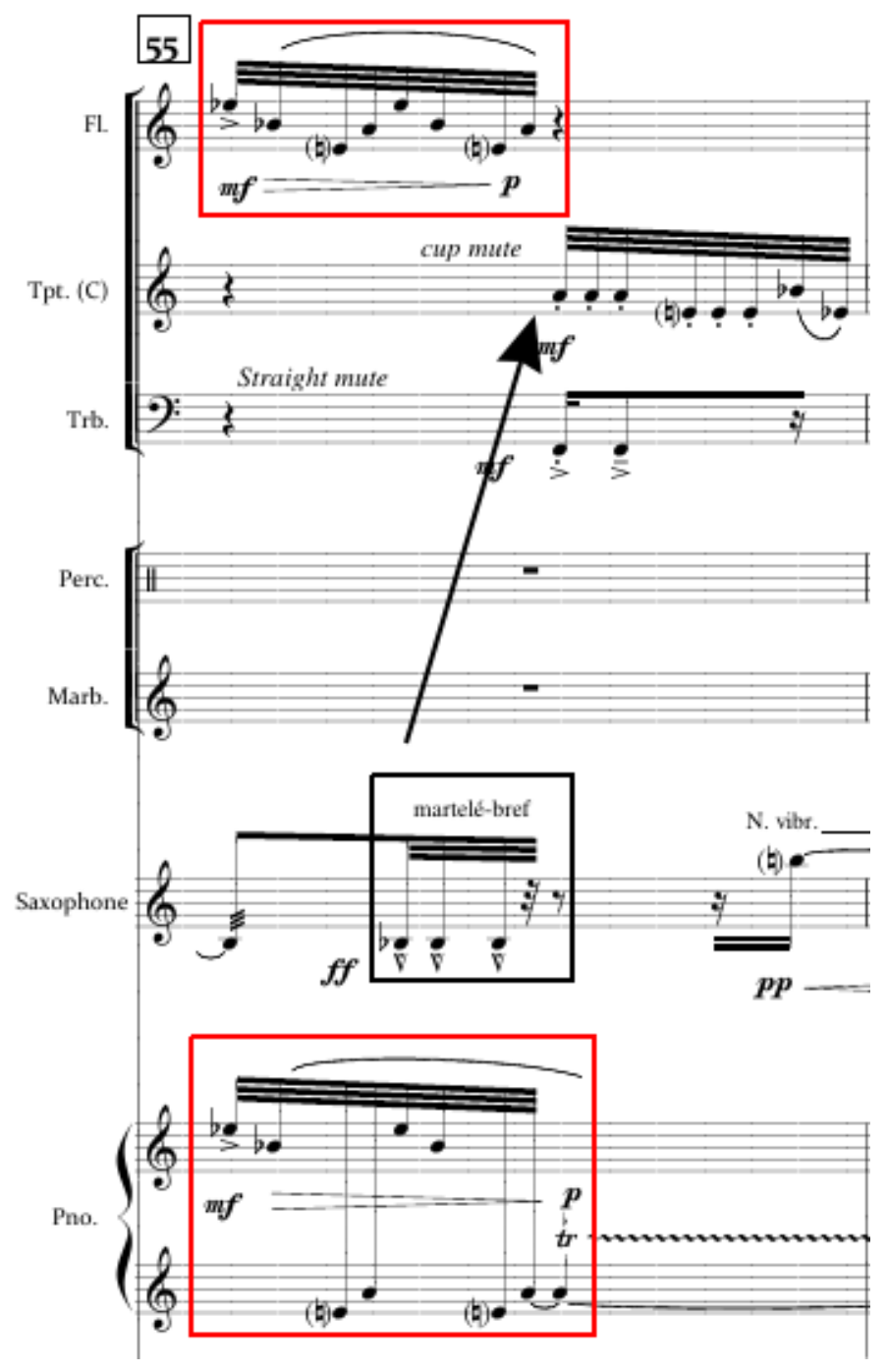

Fig. 12: Antiphonas, c. 55, deformação da continuação do gesto do saxofone (flauta e piano, em vermelho). Contágio do sax no trompete (em preto)

No decorrer da peça tornam-se mais comuns situações em que gestos do ensemble contagiam o solista, ou seja, são incorporados e modificados por ele. Na Fig. 12 observa-se uma alteração introduzida pelo trompete (a nota Sol no início do gesto) sendo absorvida pelo saxofone, que modifica a continuação do gesto. Neste exemplo também pode-se ver a utilização do intervalo Ré-Mi como eixo.

O contágio entre o estudo analítico de Antiphonas e a composição de "Intervenção verde-oliva" deu-se através destes princípios:

- notas "eixo" como ressonâncias;

- "contágio gestual": solista $\longleftrightarrow$ grupo de câmara

- ensemble ecoa e distorce gestos do solista;

- materiais do ensemble são incorporados e transformados pelo solista. 


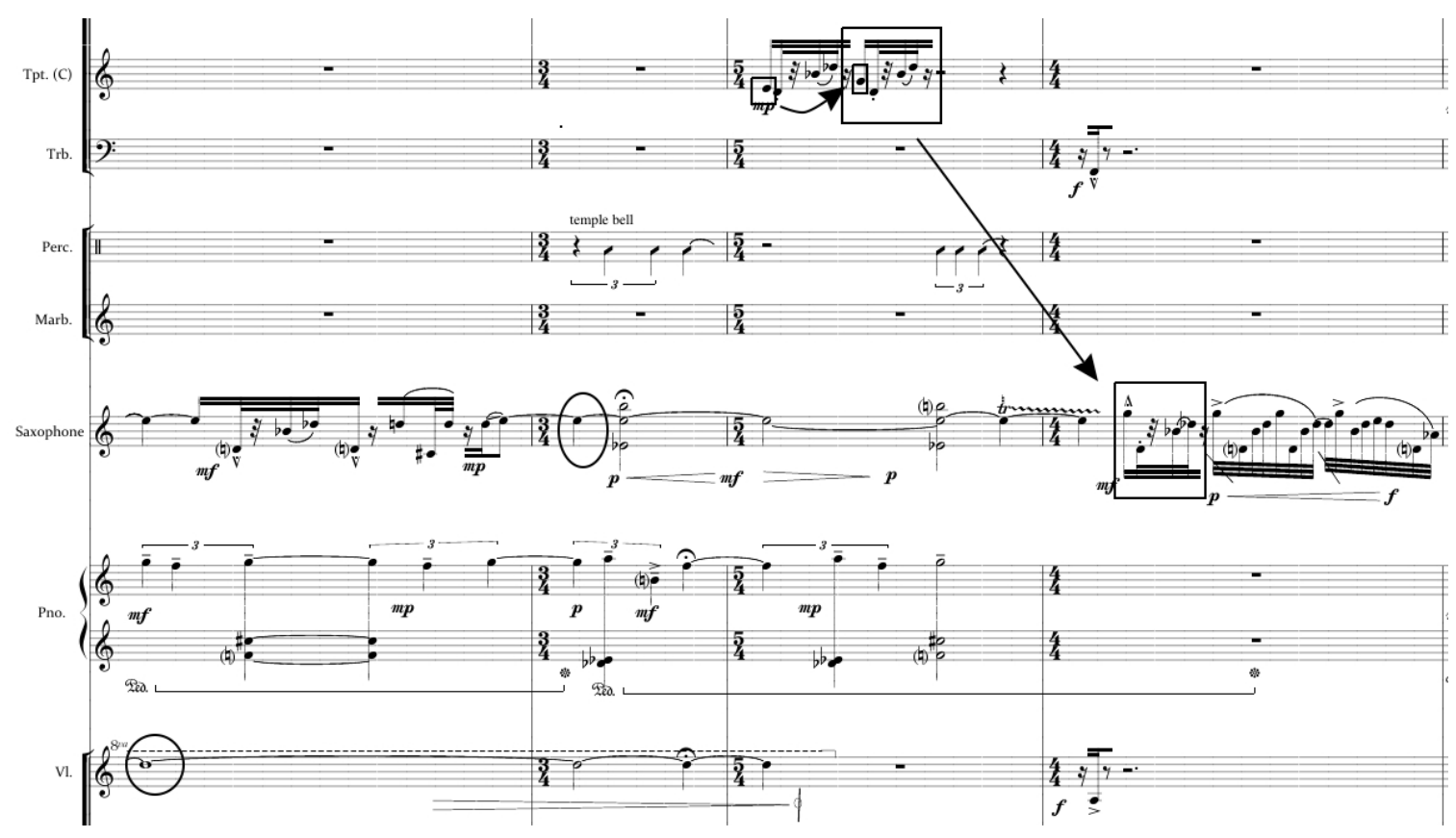

Fig. 13: Antiphonas, c. 77-81. Alteração do trompete contagia solista. Eixo em duas notas simultâneas: Ré-Mi.

Como será observado a seguir, há diferenças principalmente em relação ao contágio gestual, que inicia de maneira menos literal que os contágios de Antiphonas, concentrando-se mais nas características morfológicas dos elementos. Este tipo de contágio será referido como contágio morfológico. No primeiro exemplo, stacattos do solista dão origem à breve textura nos saxofones tenor e barítono, enquanto o saxofone alto sustenta a nota-eixo Sol.

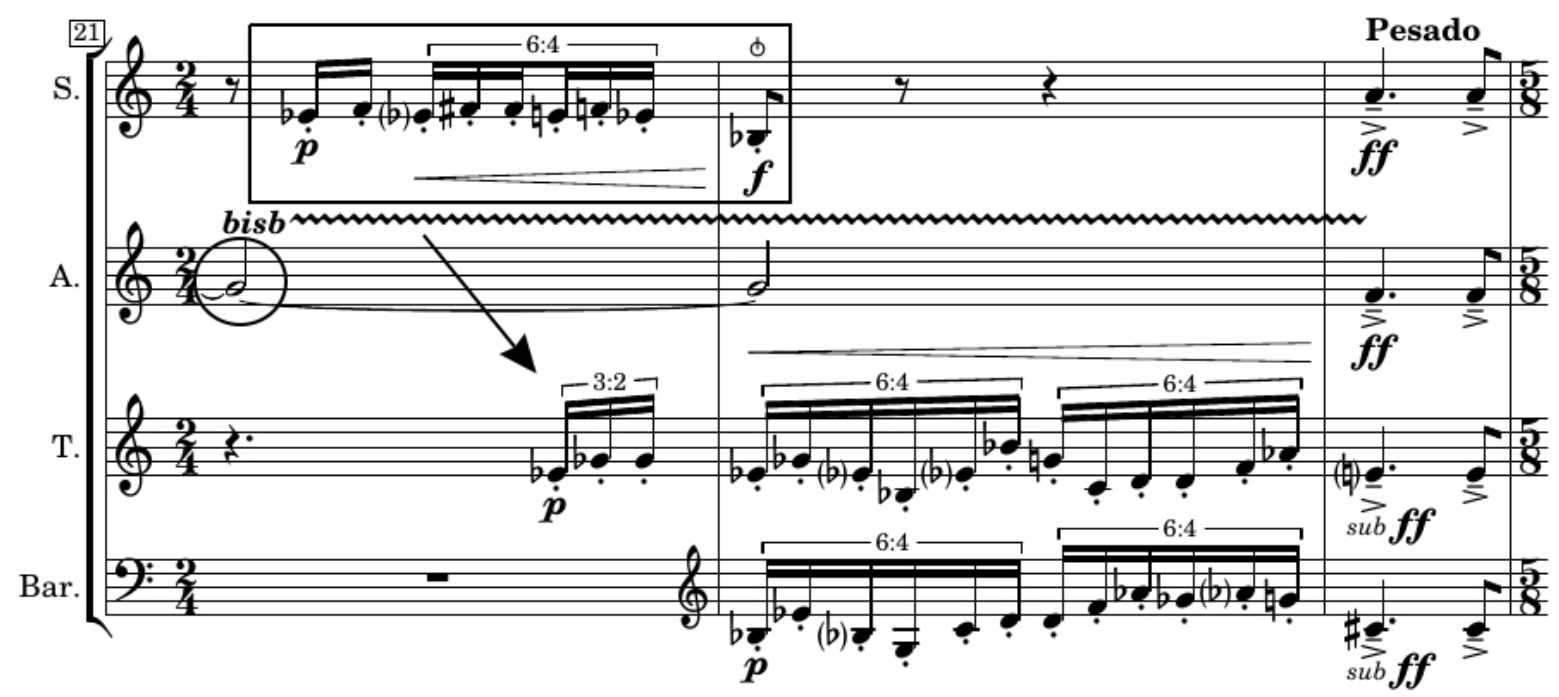

Fig. 14: "Intervenção verde-oliva", c. 21-23.

A próxima figura ilustra o contágio morfológico em direção contrária, na retomada do solo do saxofone soprano no c. 43; nesta passagem o eixo são duas notas, Lá e Sol, presentes nos trinados. Na sequência (Fig. 16), uma passagem em que o solista contagia 
a textura do ensemble com a sonoridade do frulato e depois, ao retornar, é contagiado pelos ecos distorcidos do intervalo Mi-Sib (de modo semelhante ao contágio gestual).

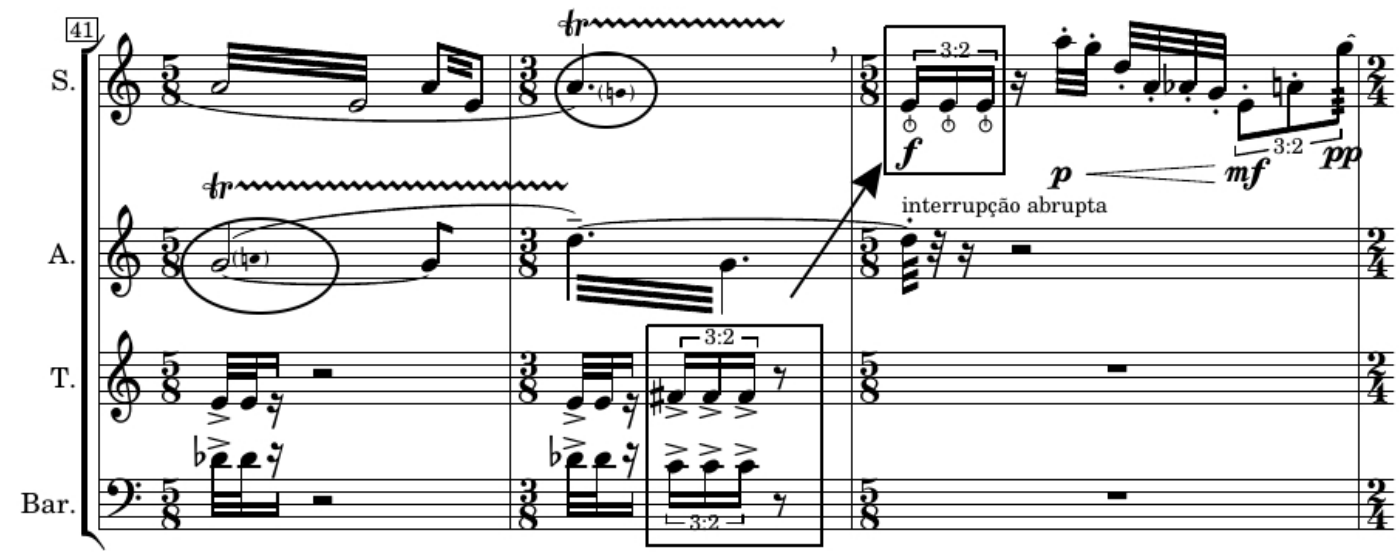

Fig. 15: "Intervenção verde-oliva", c. 41-43, notas-eixo e contágio do ensemble ao solista.

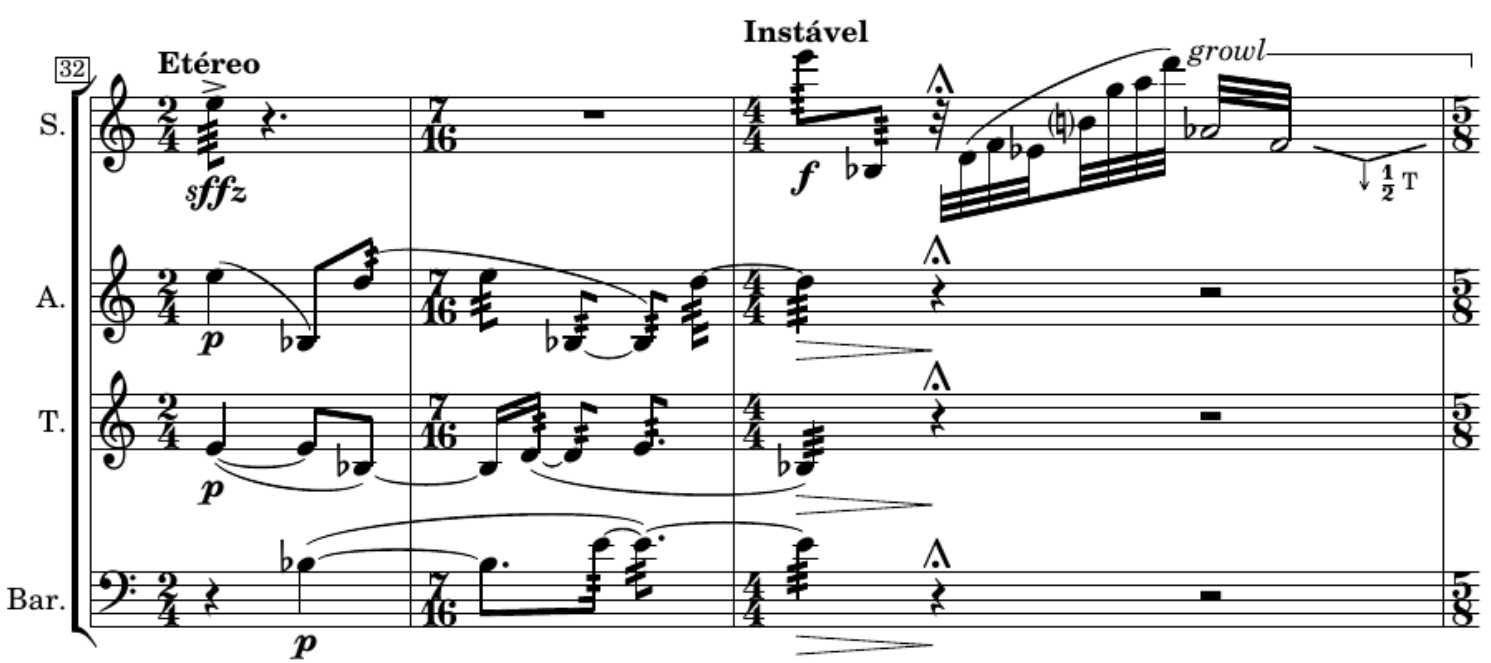

Fig. 16: "Intervenção verde-oliva", c. 32-34, contágio do solista ao ensemble (frulato) e do ensemble ao solista (intervalo e ritmo).

A análise de Antiphonas possibilitou uma conversa entre compositores, tanto verbal quanto por meio de suas obras. Como nos contágios entre obras em Inquietações, também aqui pode-se observar o contágio como uma proliferação que não se limita à imitação: os desdobramentos evoluem de maneira independente, uma vez que cada obra tem seu mundo próprio de diálogos e atravessamentos.

Em "Intervenção verde-oliva", o contágio gestual foi o princípio que se propagou e se transformou em contágio morfológico. Pode-se dizer que se trata de uma abordagem do princípio ao nível de superfície, o que não seria incorreto, pois num aprofundamento da análise de Antiphonas vê-se o princípio do contágio gestual sendo utilizado em mais níveis. 


\section{Proliferação por autocontágio em Antiphonas}

Como pôde ser observado nos exemplos anteriores, no contágio gestual entre solista-ensemble, uma alteração poderia ser absorvida, incorporada num processo de transformação distorcida e proliferar o elemento de diferença (e suas consequências). A questão, portanto, não é o elemento em si, mas a sua propagação e seus impactos ${ }^{16}$. Estes aspectos podem ser observados, para além do modo de utilização da instrumentação e constituição das texturas, na maneira como os próprios materiais proliferam, ou melhor, autoproliferam.

Para observar este modus operandi em detalhe, tomaremos como exemplo a primeira intervenção solística do sax. Ela ocorre após os 16 compassos iniciais em que o instrumento explora diversas sonoridades da nota Lá $4^{17}$ (por meio de bisbigliandos, flutuação de afinação, rugosidades de multifônicos, oscilações dinâmicas).

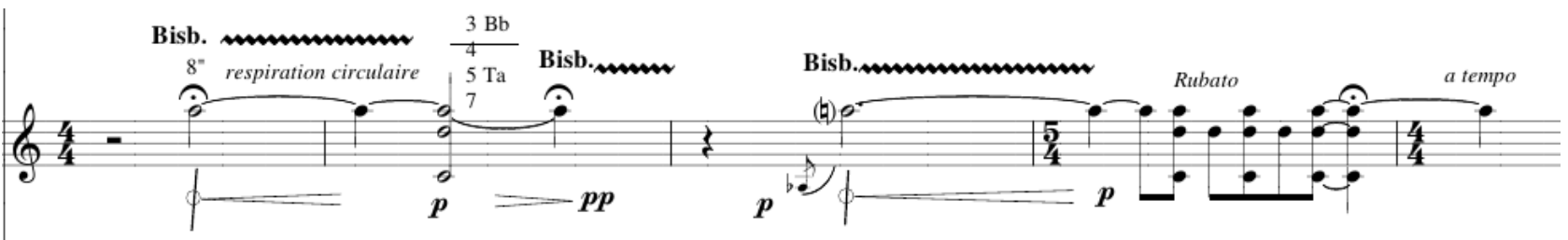

Fig. 17: Antiphonas, c. 1-3: material musical do saxofone nos primeiros compassos da peça.

Entre os compassos 7 e 9 irrompe no grupo de câmara uma textura que, diferentemente das anteriores (caracterizadas por sonoridades longas ou notas rápidas repetidas, gravitando em torno do sax), se comporta como um mosaico de pequenos fragmentos gestuais de caráter protomelódico e inverte a relação figura/fundo com o sax. Cada parte instrumental é resultado de justaposições recombinadas quanto à ordem dos elementos, que a cada momento se agrupam de modo diferente. Alguns destes gestos encontram-se na parte do piano, em que estão destacados os quatro fragmentos que a compõem:

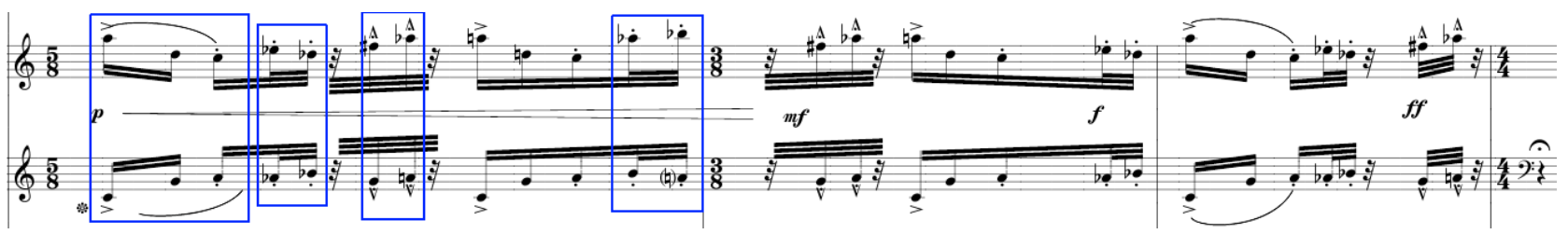

Fig. 18: Antiphonas, c. 7-9, piano. Em destaque os fragmentos permutados.

Na primeira intervenção solística do sax, que inicia no c. 17, já é possível observar a presença de alguns destes fragmentos, assim como algumas alterações introduzidas pelo sax.

\footnotetext{
16 Remete-se novamente a Deleuze e Guattari (1997, p.20): O serialismo e o estruturalismo ora graduam características segundo suas semelhanças, ora as ordenam segundo suas diferenças. As características animais podem ser míticas ou científicas. Mas não nos interessamos pelas características; interessamo-nos pelos modos de expansão, de propagação, de ocupação, de contágio, de povoamento.."
} 


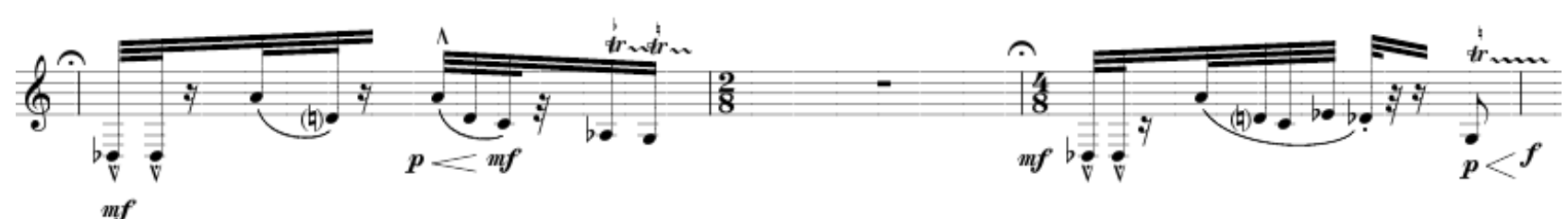

Fig. 19: Antiphonas, c. 17 a início c. 20: primeira intervenção solística do sax.

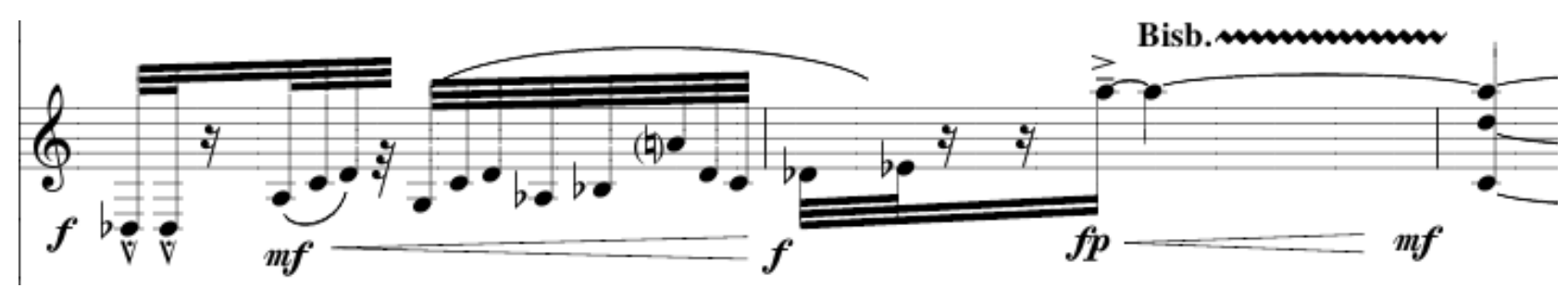

Fig. 20: Antiphonas, c. 20 a início c. 22: continuação do exemplo anterior.

Percebe-se que o compositor utiliza alguns fragmentos do piano ${ }^{18}$, porém, "recortados" de maneira diferente ao serem levados para o sax, com exceção das fusas acentuadas na nota Réb (a mais grave do instrumento), cuja sonoridade se destaca por contraste ao fluxo gestual que as segue. A figura a seguir ilustra os elementos extraídos do piano.

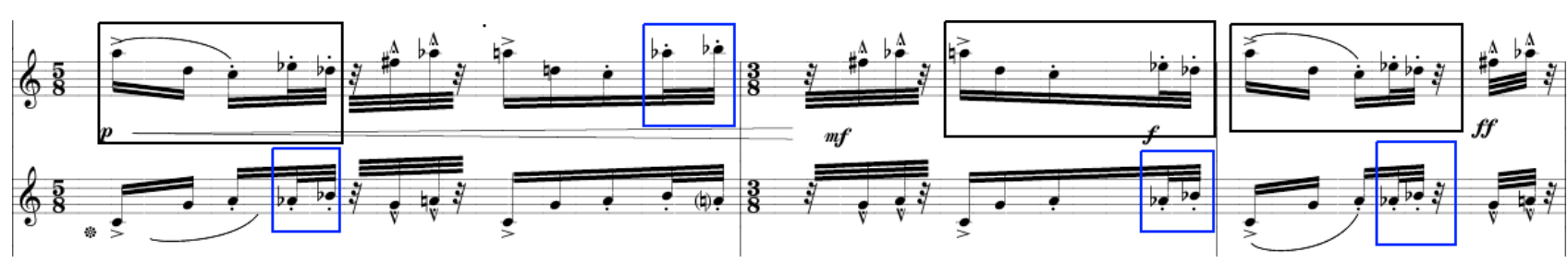

Fig. 21: Fragmentos presentes na linha do sax.

Outros fragmentos da parte do sax podem ser observados na parte da marimba, uma das camadas da mesma textura do piano nos c. 7-9. Na figura a seguir, em vermelho está destacado o material que tem relação direta com o sax (Fig. 20, c. 20, logo antes do retorno do Lá central), em cinza, relação indireta.

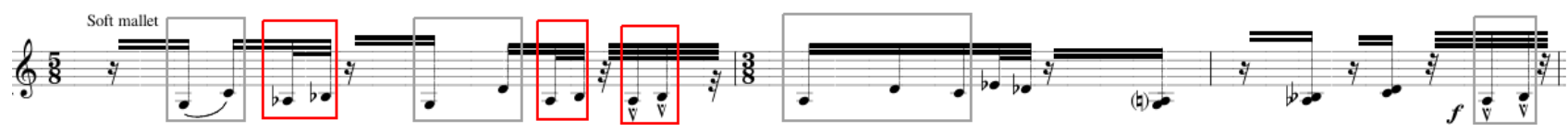

Fig. 22: Antiphonas, c. 7-9, marimba.

Especulativamente pode-se aferir aos fragmentos em cinza uma relação com a nota Sol no registro grave do sax, além dos fragmentos Lá-Dó-Ré (três fusas finais do primeiro tempo do c. 20, Fig. 20) e Sol-Dó-Ré (início do segundo tempo do c. 20, mes-

18 Também em conversa particular, o compositor afirma que compõe "olhando para trás", ou seja, extrai materiais do que já foi composto para criar seções posteriores da peça. 
ma figura). Lá-Dó-Ré pode ser visto como uma reordenação das notas do início do compasso em 3/8 da marimba; Sol-Dó-Ré, como uma mistura dos dois primeiros fragmentos destacados em cinza do exemplo anterior.

Independentemente da conclusão a que se chegue, o fato é que o compositor introduziu alterações no material do saxofone, que, como veremos, se propagam numa próxima intervenção deste mesmo instrumento, levando adiante a diferença introduzida.

Por fim, se tomarmos o primeiro gesto melódico do piano (primeiro retângulo preto, Fig. 21), separarmos as duas notas finais (como no segundo retângulo azul da Fig. 18) e alterarmos sua ordem, teremos as duas notas finais do solo do sax, que antecedem o retorno do Lá4. Esta é outra alteração que reaparece adiante na peça, como veremos.

Para constatar como as alterações introduzidas pelo saxofone vão sendo reincorporadas na linha do instrumento, gerando novos materiais por um processo de autocontágio, convém analisarmos o início da terceira intervenção solística, c. 27-28, pois a segunda introduz elementos novos em relação ao que foi exemplificado (embora também estes tenham desdobramentos no decorrer da peça).

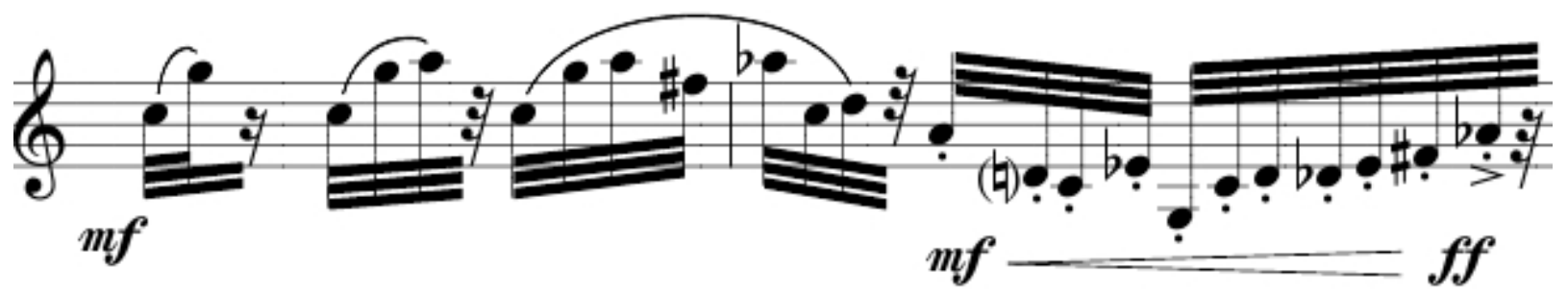

Fig. 23: Antiphonas, c. 27-28, saxofone: início da terceira intervenção solística.

O fim do solo ocorre no c. 32:

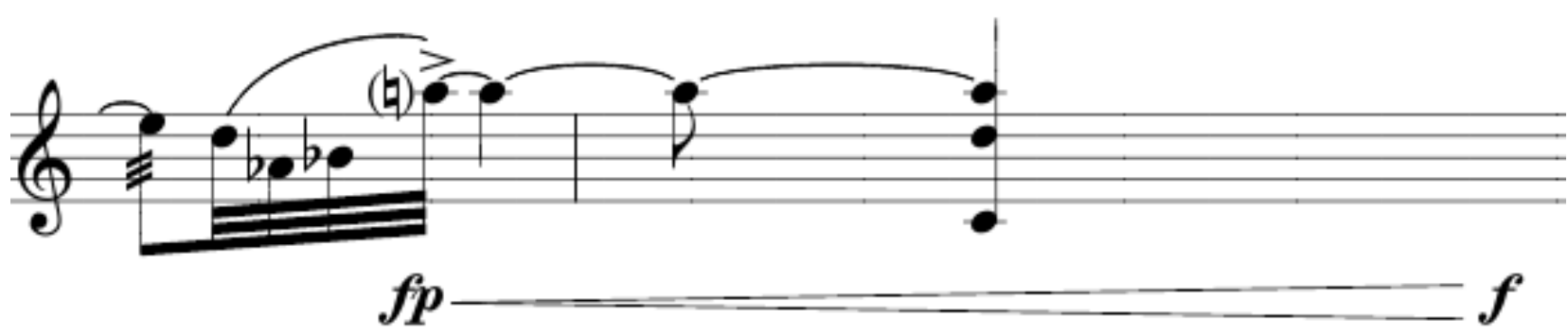

Fig. 24: Antiphonas, final do c. 32 e início do c. 33, saxofone.

Em esboços gentilmente cedidos pelo compositor, vê-se a anotação do que viria a ser o início do solo do sax (sem o Réb), e abaixo, na mesma página, a mesma linha notada ao reverso, com uma clave invertida e uma notação, também invertida, onde se lê "mecanismo automático de inversão": 

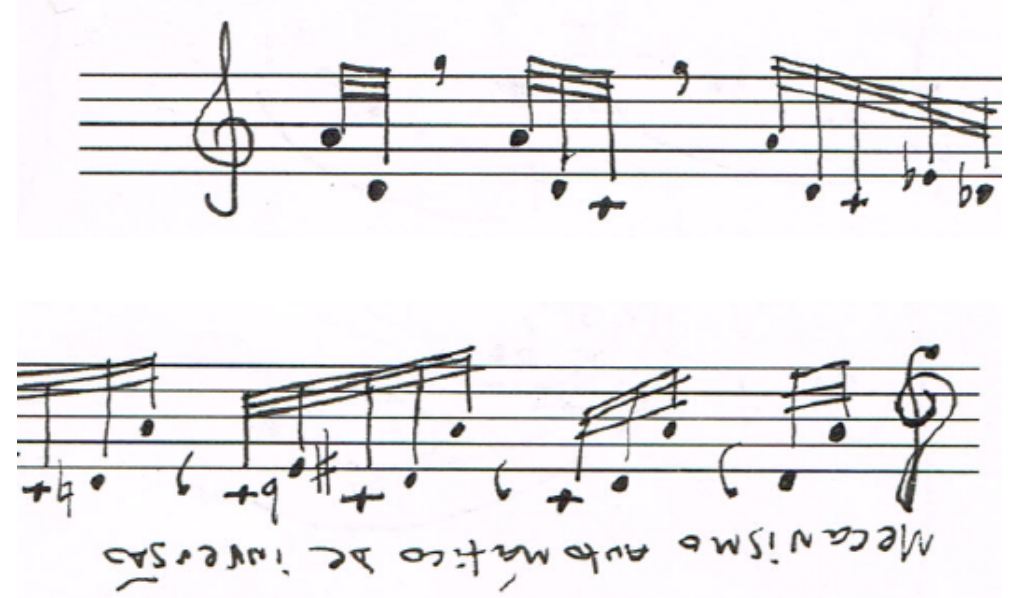

Fig. 25: Dois fragmentos do esboço cedido pelo compositor.

A partir deste recurso visual (que nos remete à Ma fin est mon commencement, de Guillaume de Machaut), verifica-se que os fragmentos antes isolados no início do solo agora encontram-se justapostos e invertidos.

A finalização do legato (c. 27 e primeiro tempo do 28), com as notas Dó-Ré, remete às diferenças introduzidas pelo sax em relação aos materiais do ensemble comentados anteriormente, a respeito do primeiro solo: Lá-(Dó-Ré) e Sol-(Dó-Ré).

Na sequência do fluxo gestual, trecho em staccato, fica mais clara a ideia de autocontágio: alterações introduzidas pelo saxofone são incrustadas em meio a fragmentos do primeiro solo, consequentemente produzindo novas configurações gestuais que poderão, enquanto possibilidade, ser reaproveitadas para constituir novos materiais em momentos subsequentes da peça, num processo iterativo.

$\mathrm{Na}$ figura a seguir, fragmentos do primeiro solo estão em preto, com colchetes indicando os "pedaços" utilizados na constituição do trecho em análise (Fig. 23, c. 28), que está em azul. As linhas contínuas indicam as relações diretas (transpostas ou não), as linhas tracejadas indicam relações indiretas (quando na peça o ritmo dos fragmentos indicados em colchetes é idêntico, as notas diferem, mas há semelhança intervalar).

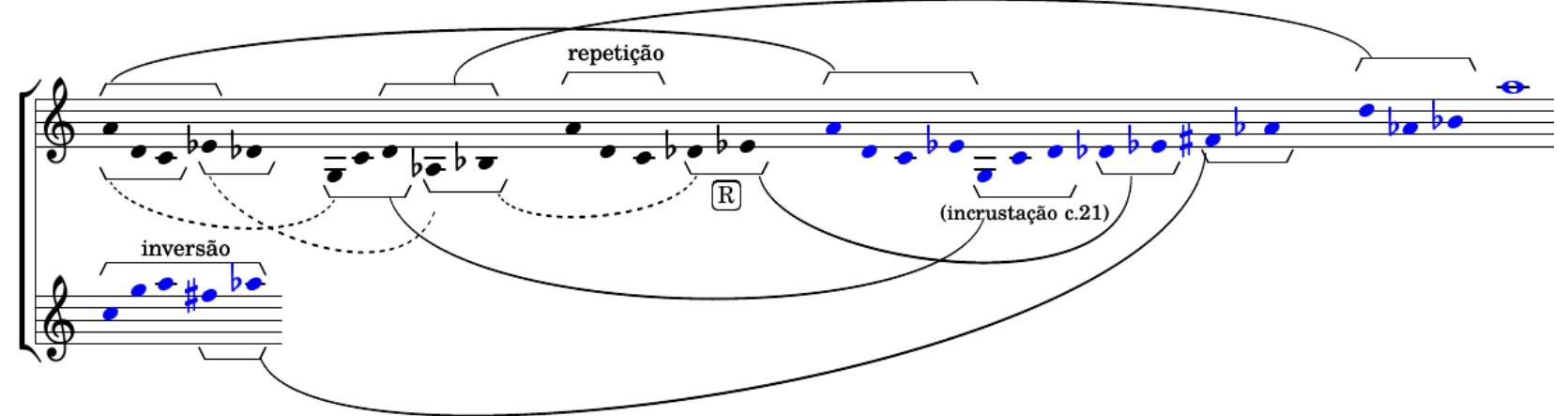

Fig. 26: Processo de autocontágio no saxofone, engendrando o material do terceiro solo.

Observa-se na figura como resultantes das recombinações dos fragmentos vão sendo incorporadas e se propagando, como na finalização do solo, antes do retorno do Lá4, 
em que o compositor recorta do segundo grupo de notas a porção Ré-Láb-Sib (indicado pelo colchete superior), combinação intervalar que não existia antes da justaposição dos fragmentos Sol-Dó-Ré (já mencionado) e Láb-Sib (presente na linha da marimba).

São diversas as semelhanças dos procedimentos apresentados nesta análise com o conceito de autopoiese, que Lima constantemente refere em seus relatos composicionais (conceito dos biólogos chilenos Humberto Maturana e Francisco Varela). Contudo, ele o emprega a respeito da "possibilidade de construção de uma obra musical a partir de uma estrutura harmônica previamente estabelecida" (LIMA, 2014, p.122) e da "possibilidade de estabelecer ramificações de certos materiais harmônicos ao longo da obra" (LIMA, 2017, n.p., tradução nossa) ${ }^{19}$, ou seja, o compositor explicita apenas sua abordagem do conceito quando se refere à dimensão harmônica.

\section{Conclusão: poética do contágio}

Do ponto de vista do material melódico e do fluxo gestual, o autocontágio em Antiphonas refere-se ao processo que incorpora variações de pequenas variações, apagando sua origem e proliferando diferenças, num processo autogerativo muito semelhante à maneira como Lima vê seu trabalho harmônico. Não foi possível concluir se se trata de um processo sistemático, no sentido de haver regras muito definidas; ao contrário, a impressão é a de uma utilização bastante livre. Tal impressão faz sentido na medida em que o contágio, tanto nas dinâmicas intramusicais quanto nos diálogos entre compositores e obras, não é um processo de controle, mas de proliferação de diferenças.

Deleuze e Guattari (1997, p.18) afirmam que o devir se propaga por contágio e aliança, não se tratando de correspondência de relações, semelhança, identificação ou imitação. Isto ressoa com a proposição de Ferraz (2012a, p.295), quando cruza as ideias de conversas e reescrituras: tentar imitar sem esquecer a própria língua. ${ }^{20}$

O contágio, propagando diferenças, traz mais do que aquilo que se espera.

Em Inquietações, estudos analíticos despretensiosos foram um mote para uma conversa com Berio, buscando descobrir como o compositor abordava o clarinete e como criava a sensação de surpresa somente com as articulações e modos de ataque no início de sua peça para violino. Ou seja, a análise se deu para tentar resolver questões que se apresentavam no momento da composição, numa troca de experiências

\footnotetext{
19 Original: "It is from this "autopoietic" assumption that I've started thinking about the possibility of establishing ramifications of a certain harmonic material throughout a work.".

20 Deleuze e Guattari estão rejeitando a imitação no sentido de "repetição do mesmo", pois esta bloqueia a propagação do devir, ao passo que Ferraz utiliza o conceito de imitação no sentido atribuído por Gabriel Tarde em Les lois de l'imitation. Segundo Ferraz (2008), há duas ideias de repetição, que, postas de maneira extremamente sintética, seriam: 1) a "repetição do mesmo", o que implicaria a utilização de um método de redução das nuances para que se pudesse atribuir uma essência, e, assim, "anexa-se ao repetido uma identidade que não estava ali"; 2 ) a "repetição do diferente", em que o que se repete não é uma coisa, uma ideia ou um som, mas a "condição de invenção". Em La formule de la ritournelle, afirma o compositor: "O conceito de Ritornelo retoma, de um certo modo, a fórmula da repetição de Les lois de l'imitation de Gabriel Tarde. Operar a repetição do diferente é, portanto, de certa forma 'imitar a invenção': imitar a invenção falsificando a invenção, imitando as forças não formadas da invenção, aí está o ponto sempre nascente de uma nova invenção" (FERRAZ, 2012b, n.p. - tradução nossa). Em conversas particulares Ferraz (2020) sintetiza: "A imitação transborda o imitado. Ela sempre faz passar pelo que imita forças que o original não tinha.."
} 
entre compositores distanciados no tempo e no espaço. Não se esperava encontrar a técnica das rotações quando se buscava ver a utilização do instrumento na Sequenza IXa; tampouco o princípio de compensação quando se queria compreender a dinâmica da introdução da Sequenza VIII. Ainda assim, rotações e princípio de compensação se diferenciaram do modo como são utilizados nas peças de origem.

Em "Intervenção verde-oliva", a composição ocorreu após ouvir as propostas e ideias de Lima, ao mesmo tempo em que se propunha uma leitura para sua obra, do ponto de vista de outro compositor. Mais do que a tradicional abordagem da análise como estudo do qual se extraem técnicas a serem aplicadas, "Intervenção" foi o espaço aberto em Tons de amarelo patético para que o contágio com a análise pudesse se manifestar. Novamente, proliferam diferenças: do contágio gestual surgiu o contágio morfológico.

"O contágio é ao mesmo tempo povoamento animal e propagação do povoamento animal do homem" (DELEUZE; GUATTARI, 1997, p.24). Propagando-se por meio de conversas e análises, a maneira como Lima trabalha a proliferação dos materiais musicais em suas peças ${ }^{21}$ pode "contaminar" o processo criativo de compositoras e compositores. Deste modo, este fazer do e por contágio, esta poética do contágio, alastra-se epidemicamente.

\section{Agradecimentos}

Agradeço a Rodrigo Lima e Silvio Ferraz pelas contribuições com este trabalho, tanto nas respostas atenciosas às minhas dúvidas quanto na gentil disponibilização de materiais de acervo pessoal.

\section{Referências}

BELCASTRO, Luca. Método para procesos compartidos: etapas y pasos. [S. l.: s. n.], 2017. E-book. Disponível em: http://belcastro.germinaciones.org/Libros/metodo_ es.html. Acesso em: 21 ago. 2019.

BERIO, Luciano. Sequenza IXa: per clarinetto solo. Milano: Universal Edition, 1980. Partitura.

DELEUZE, Gilles. Francis Bacon: lógica da sensação. Equipe de tradução (org.): Roberto Machado. Rio de Janeiro: Jorge Zahar, 2007.

DELEUZE, Gilles; GUATTARI, Félix. Devir Intenso, Devir Animal, Devir Imperceptível. In:

\footnotetext{
21 Certamente não é possível afirmar, com a análise de uma única peça, que o autocontágio seja uma característica do fazer composicional de Lima, embora o compositor veja em Antiphonas uma continuação de peças anteriores, como Elegia em Azul, ou mesmo peças mais antigas, como Gestuelle, ao menos do ponto de vista da estruturação harmônica e da construção de um "reservatório gestual" (a partir de improvisações ao piano) com conteúdo derivado de "matrizes harmônicas" (como explica em: LIMA 2009).
} 
DELEUZE, Gilles; GUATTARI, Félix. Mil Platôs: capitalismo e esquizofrenia. Vol. 4. Trad. Suely Rolnik. São Paulo: Ed. 34, 1997. p. 115-170.

DELEUZE, Gilles; GUATTARI, Félix. Introdução: Rizoma. In: DELEUZE, Gilles; GUATTARI, Félix. O que é a Filosofia? Trad. Aurelio Guerra Neto e Celia Pinto Costa. São Paulo: Ed. 34, 1995. p. 11-37.

FERRAZ, Silvio. Breve nota de apresentação. In: FERRAZ, Silvio (org.). Notas.Atos. Gestos. Rio de Janeiro: 7Letras, 2007.

FERRAZ, Silvio. Dúvida conceitual. Mensagem recebida por <alexandre.ficagna@gmail. com> em 1 jun. 2020.

FERRAZ, Silvio. Encontro com... a Análise Musical. Cadernos de Estudo: Análise Musical, São Paulo, Atravéz, n. 6/7, fev. 1994. Entrevista concedida a Carlos Kater.

FERRAZ, Silvio. Escutas e Reescritas. In: TRAGTENBERG, Livio (org.). O ofício do compositor hoje. São Paulo: Perspectiva, 2012a. p. 285-306.

FERRAZ, Silvio. La formule de la ritournelle. Filigrane, Paris: Sampzon, v. 13, 2012b.

FERRAZ, Silvio. Música e repetição: a diferença na composição contemporânea. São Paulo: Educ, 1998.

FERRAZ, Silvio. Repetição e identidade. Texto de palestra apresentada no evento Impressiones Sonoras. Berlim: Universität der Künste, 2008. Não publicado.

FICAGNA, Alexandre. Conversas e diálogos como parte do processo criativo de Inquietações, para clarinete solo. In: CONGRESSO DA ASSOCIAÇÃO BRASILEIRA DE PESQUISA E PÓS-GRADUAÇÃO EM MÚSICA, 28., 2018, Manaus. Anais [...]. Manaus, 2018. p. 1-10.

FICAGNA, Alexandre. Inquietações (in memorian Célio Remuzzi). Vórtex, Curitiba, v. 5, n. 1, p. 1-12, 2017a.

FICAGNA, Alexandre. Tons de amarelo patético. 2017b. Partitura não publicada.

KLEE, Paul. Sobre arte moderna e outros ensaios. Prefácio e notas: Günther Regel. Trad. Pedro Süssekind. Rio de Janeiro: Jorge Zahar, 2001.

LIMA, Rodrigo. Antiphonas, for alto saxophone and ensemble. 2014. Edição não publicada cedida pelo compositor. 
LIMA, Rodrigo. Composing is a discovery act. Art music review, n. 33, dez. 2017. Disponível em: https://www.revista-art.com/composing-is-a-discovery-act. Acesso em: 13 mar. 2020.

LIMA, Rodrigo. Da nota ao som: explorando territórios harmônicos. Dissertação (Mestrado em Música) - Instituto de Artes, Universidade Estadual de Campinas, Campinas, 2009.

LIMA, Rodrigo. Resposta - eco antifonal distorcido. Mensagens recebidas por <alexandre.ficagna@gmail.com> entre 1 e 8 jun. 2020.

MALT, Mikhaïl. Brian Ferneyhough et l'aide informatique à l'écriture. In: SZENDY, Peter (org.). Brian Ferneyhough. Paris: L'Harmattan, Ircam, 1999. p. 61-106.

SALLES, Paulo de Tarso. O estatuto da composição musical pós-Boulez. Opus, Goiânia, v. 16, n. 2, p. 8-14, dez. 2010. 